\title{
Policy Options for Promoting Foreign Direct Investment in the Least Developed Countries
}

\author{
Karl P. Sauvant and Padma Mallampally
}

\begin{abstract}
Foreign direct investment (FDI) plays an important role in the world economy and has the potential to contribute towards accelerating the process of economic growth and sustainable development in the least developed countries (LDCs). The paper provides a brief overview of recent trends and patterns in FDI flows to the LDCs, and then takes stock of the policies, programmes and measures pursued by host and home countries and by international organizations to stimulate FDI flows to LDCs and increase their benefits for these countries. It then lays out a number of policy proposals on how flows to LDCs, and the benefits associated with them, can be enhanced. Finally, it outlines some options for international action to strengthen such efforts - proposals and options that are also relevant to other developing countries.
\end{abstract}

Keywords: Foreign direct investment, Least Developed Countries, policy options, development

\section{FDI in the LDCS: An overview}

Foreign direct investment (FDI) can serve as an important complement to domestic investment and capacity building for the growth and development of the LDCs. The distinctive aspect of FDI is that it brings in a package of resources -- capital, technology, skills, management know-how, and marketing capabilities -- along with production activities, to a host economy. While these resources and capabilities are intended for use in the host-country affiliates and help maximize profits for the investing transnational corporations (TNCs), they also have a number of direct and indirect effects that can, under appropriate conditions, be of considerable benefit for a host economy. They can generate not only products for local consumption or for export, income and employment but also linkages and spillovers that strengthen the capabilities of domestic firms and human resources, contributing to capacity-building and accelerated growth in the host economy as well as structural change and industrial upgrading. When the firm-specific assets that form the basis for international production through FDI are properly leveraged and integrated with country-specific advantages of host economies, FDI has the potential to increase consumer welfare, provide jobs, raise labour and environmental standards, and contribute to improved living standards and poverty alleviation. ${ }^{1}$

There has been a steady rise in FDI flows to the LDCs since the beginning of the 2000s, reflecting improvement in both economic and policy factors influencing such flows. However, there is considerable

\footnotetext{
${ }^{1}$ Alan M. Rugman and Jonathan P. Doh, Multinationals and Development (Yale University Press, 2008), chapter I, available at http://Yalepress.yale.edu/yupbooks/book.asp?aspn=9780300115611.
} 
Policy Options for Promoting FDI in the LDCs

scope for further increases in FDI flows, for their geographic and sectoral diversification, and for mobilizing them towards accelerating the LDCs' development process.

\subsection{Trends and relative importance}

FDI flows to the LDCs as a group has risen steadily since the turn of the century. Average annual FDI flows to the LDCs amounted to US\$ 25 billion in 2011-2013, more than three times the average flow of US\$ 8 billion in 2001-2003 (annex table). ${ }^{2}$ The rate of increase was slightly lower than that in FDI flows to all developing countries, which rose from an average of US\$ 196 billion per year to US\$ 744 billion per year between the same time periods, but higher than that of average annual FDI flows world-wide, which rose to slightly more than double their value over the two periods. Reflecting the growth in inflows, the stock of FDI in the LDCs grew from US\$ 42 billion in 2001 to US\$ 211 billion in 2012.

Although the share of the LDCs in total flows of FDI to developing countries remains low, at 3.3 per cent in 2011-2013 (1.7 per cent of world inflows), FDI is more important, relative to domestic investment, in the LDCs than in developing countries as a group: In 2011-2013, FDI inflows as a percentage of gross fixed capital formation stood at 13 per cent in the LDCs, as compared with 9 per cent in all developing countries, 8 per cent in developed countries and 9 per cent in the world as a whole (annex table). The stock of FDI relative to GDP in 2012 was 23 per cent in the LDCs, as compared with 30 per cent in all developing countries, 33 per cent in developed countries and 32 per cent world-wide.

FDI flows are by far the largest private capital flows to the LDCs: in fact, during 2001-2010, private capital flows other than FDI (mainly portfolio investment and bank lending) were close to zero. ${ }^{3}$ Furthermore, from 2006 onwards, FDI flows to the LDCs exceeded bilateral official development assistance (ODA) (that is, ODA excluding that from multilateral organizations), and reached more than half the amount of total ODA that they received. ${ }^{4}$ The trends in FDI flows and their importance, relative to gross domestic capital formation and ODA, signal that although the absolute amount of FDI they receive is small, the LDCs are becoming more attractive investment destinations, and that the contributions of FDI to capacity building in their economies can be expected to grow. This nascent dynamism is also reflected in the growth of outward FDI from the LDCs, as will be briefly discussed below.

\subsection{Geographic and sectorial distribution}

The 34 African economies among the LDCs accounted for some 79 per cent of the LDCs' inward FDI flows in 2010-2013, the 14 Asia-Pacific economies for 20 per cent, and the Caribbean island of Haiti, for 1 per cent. ${ }^{5}$ This represents a noticeable shift in the distribution of inward FDI between the African LDCs and those in the Asia-Pacific region, which had received 89 per cent and 10 per cent, respectively, of the inflows in 2001-2003. More than four fifths of the flows in 2011-2013 went to the top 10 recipients --

\footnotetext{
${ }^{2}$ All data on FDI are from or based on data from the UNCTAD FDI database (http://unctadstat.unctad.org), unless otherwise indicated.

${ }^{3}$ Information on other private capital flows and ODA is from UNCTAD, Foreign Direct Investment in LDCs: Lessons Learned from the Decade 2001-2010 and the Way Forward (New York and Geneva: United Nations, 2011), p. 3.

${ }^{4}$ As sources of finance, the two cannot entirely be substituted for one another because ODA is for infrastructure, budget support, etc., while FDI looks for profit-making opportunities.

${ }^{5}$ Based on the data provided in the Annex table.
} 
Mozambique, Sudan, Democratic Republic of Congo, Myanmar, Equatorial Guinea, United Republic of Tanzania, Zambia, Bangladesh, Cambodia, and Uganda (most of them mineral-abundant countries), -- in that order.

FDI in the LDCs has traditionally been directed largely towards natural resource extraction. However, there are signs that this may be changing. Although data are lacking on the sectoral distribution of FDI flows and stock, data on the estimated value of greenfield FDI projects (i.e., newly built facilities) -which account for the bulk of FDI in the LDCs -- throw some light on these changes. During 2003-2010, the shares of the primary, manufacturing and services sectors in the estimated value of greenfield FDI projects were 55 per cent, 28 per cent and 17 per cent, respectively. In 2011-2013, the shares stood at 21 per cent, 28 per cent and 51 per cent, respectively. ${ }^{6}$ One noteworthy development in recent years is the rise in FDI in land deals for agriculture in some LDCs, some of it backed by home-country governments. ${ }^{7}$

There are also distinct signs that the geographical distribution of FDI in the LDCs by source country is changing. Judging from a comparison of the value of FDI projects in the LDCs ${ }^{8}$ by source region in 2003 and 2010, although FDI from Europe continued to account for the largest share (20-30 per cent), and that from developed countries as a group for over 50 per cent, the share of FDI from developing and transition economies had risen considerably (from around 25 per cent to over 40 per cent). While investment in the LDCs from several emerging economies (including China, India, Malaysia, South Africa) is on the rise in both absolute and relative terms, the rise and importance of FDI from China is particularly striking: between 2003 and 2008, Chinese FDI flows to the LDCs rose from US\$ 45 million to US\$ 981 million, and, in 2008, 34 LDCs were hosts to Chinese FDI. ${ }^{9}$ In 2012, Lao PDR, Cambodia and Angola were the top LDC host economies among the 27 LDCs that were hosts to FDI from China ${ }^{10}$, reflecting the fact that, while extractive industries attract large amounts of Chinese FDI, other industries are important targets for it as well. Data for 2011-2013 show that developing home economies accounted for close to half (46 per cent) of the estimated value of inward greenfield FDI projects in the LDCs. ${ }^{11}$ In recent years, India was the leader among developing countries in terms of greenfleld FDI in LDCs (with nearly US\$ 8 billion in announced greenfield investments in the LDCs in 2012-2013), followed by South Africa and Nigeria; China topped the list of countries, developing as well as developed, in terms of FDI through cross-border

\footnotetext{
${ }^{6}$ Based on data for 2011 from UNCTAD, World Investment Report 2013: Global Value Chains. Investment and Trade for Development (Geneva: United Nations, 2013), op. cit., table D, p. 73, and data for 2012-2013 from UNCTAD, World Investment Report 2014: Investing in the SDGs. An Action Plan (Geneva: United Nations, 2014), table D, p. 82, available at http://www.unctad.org/en/PublicationChapters/wir2014ch2_en.pdf (last visited 26 June 2014).

${ }^{7}$ See Lorenzo Cotula, Sonja Vermeulen, Rebeca Leonard, and James Keeley, "Land grab or development opportunity? Agricultural investment and international land deals in Africa", IIED/FAO/IFAD, London/Rome, 2009, available at: www.ifad.org/pub/land_grab.pdf (last visited August 22, 2014); and Hem Socheth, "Foreign investment in agriculture in Cambodia: a survey of recent trends", TKN Report, Trade Knowledge Network, International Institute for Sustainable Development, Geneva, Switzerland, December 2012, available at: www.iisd.org/tkn (last visited September 7, 2014).

8 As measured by the value of net cross-border M\&A sales plus that of greenfield projects. See, UNCTAD, Foreign Direct Investment in LDCs, op. cit., figure 1.9, p. 10.

${ }^{9}$ UNCTAD, Foreign Direct Investment in the LDCs: Lessons Learned and the Way Forward, op. cit., table 1.5, p.11.

${ }^{10}$ UNCTAD, Bilateral FDI Statistics 2014, China, available at http://unctad.org/Sections/dite_fdistat/docs/webdiaeia2014d3_CHN.pdf (last visited 29 April 2014).

${ }^{11}$ Based on data for 2011 from UNCTAD, World Investment Report 2013, op. cit., table E, p. 73, and on data for 2012-2013 from UNCTAD, World Investment Report 2014, op. cit., table E, p. 82.
} 
mergers and acquisitions (M\&As) in the LDCs, accounting for nearly US\$ 6 billion of the LDCs' crossborder M\&A sales in 2012-2013. ${ }^{12}$

\subsection{Determinants of FDI}

The location-specific factors motivating firms with the necessary ownership-specific and internalization advantages to engage in direct investment abroad have been classified into natural-resource-seeking, market-seeking, efficiency-seeking, and created-asset-seeking ones. ${ }^{13}$ Whether firms with such advantages and motivations choose one location or another for their FDI depends on the attractiveness of potential host countries in terms of the location-specific advantages sought by firms (as well as the marketing efforts made to bring a country's advantages to the attention of TNCs). The LDCs, with their relatively low GDP per capita and as-yet low degree of development of their human assets, can be considered to be at a relative disadvantage in attracting FDI, and in the first stage of what has been called the investmentdevelopment path, ${ }^{14}$ except perhaps when the resources sought are natural, as in the case of agriculture or mining or, in some cases, cheap labour. While the resource-seeking motivation, primarily in mining, quarrying and petroleum but also land for agriculture (e. g., in Cambodia and some African countries), has indeed been the largest driver of FDI in the LDCs traditionally, as the sectoral distribution of FDI shows, it is not the only one, and there are signs that its importance is diminishing. That indicates that the LDCs have other competitive advantages as locations for FDI, or can develop and strengthen such advantages, except for created assets that require strong technological capabilities.

In addition to offering opportunities for manufacturing that are related to FDI in extractive activities, the LDCs, particularly those with large populations, can offer opportunities for market-seeking FDI in other manufacturing industries, such as the food, beverage and tobacco industry which attracted US\$ 1 billion in greenfield FDI projects in their economies in 2011-2012. They can, moreover, attract FDI to services such as electricity, gas and water, transport, storage and communications, and financial services (especially banking), which also attracted noticeable amounts of FDI through greenfield projects in the LDCs in 2011-2013. ${ }^{15}$ Finally, LDCs can also obtain efficiency-seeking FDI in low-cost labour-intensive manufactures for export, as suggested by the early experience of Bangladesh in the ready-made garment industry, in which that country continues to be an important exporter through various contract manufacturing activities, and the experience of Cambodia, which attracts considerable FDI, especially

\footnotetext{
${ }^{12}$ UNCTAD, World Investment Report 2014, op. cit., tables E and C, p. 82.

${ }^{13}$ John H. Dunning and S. Lundan, Multinational Enterprises and the Global Economy (Cheltenham: Edward Elgar, 2008), chapter 3.

${ }^{14}$ R. Narula and John H. Dunning, "Multinational enterprises, development and globalization: Some clarifications and a research agenda", Oxford Development Studies, vol. 38, No. 3 (September 2010), pp. 263-287. The first stage of the investmentdevelopment path refers to a situation in which both inward and outward FDI flows are small, reflecting a country's lack of location-specific advantages as a host for FDI as well as ownership-specific advantages for outward FDI, due to a combination of factors such as a limited domestic market, a low-skilled labour force, limited technological capabilities and institutions, or weak government policies.

${ }^{15}$ UNCTAD, World Investment Report 2013, op. cit., table D, p. 73, and World Investment Report 2014, op. cit., table D, p. 82. Judging from the data on FDI stock and annual flows, it seems that a substantial portion of announced infrastructure investments in the LDCs during 2003-2013 did not generate FDI inflows, indicating that project shares could be shared among different types of sponsors and that a large part of foreign sponsors' investment commitments were financed with non-equity modes of investments by TNCs, debts, structured finance, or bilateral and multilateral donor funding (UNCTAD, World Investment Report 2014 , op. cit., p. 84 ).
} 
from China, to the garment industry. ${ }^{16}$ The extent to which such potential is or can be exploited depends on the institutional and policy framework governing FDI, the overall climate for business or economic activities and the effectiveness with which such investment is promoted.

\subsection{Outward FDI from LDCs}

Traditionally, the attention of policy makers has been on inward FDI and its role in contributing to development, in particular by building domestic capacity that is internationally competitive. Inward FDI is the focus of this paper, as well; however, a brief look at FDI from the LDCs may be appropriate here, as the international competitiveness of domestic firms can also be strengthened through outward FDI. The principal reasons are twofold. The first is that outward FDI provides firms with better access to foreign markets to produce - and deliver -- goods and services to those markets, including through tradesupporting outward FDI. The other principal reason is that outward FDI provides firms with better access to resources of all kinds (including know-how, technology and management experience) which, in turn, help to increase the competitiveness of parent firms. It is for these reasons (as will be discussed below) that all developed countries, as well as a rising number of developing countries, support their firms seeking to invest abroad.

Indeed, a number of LDCs have also become home countries for outward FDI, with 24 of them having reported some outward FDI flows during 2010-2013 (annex table). This suggests that some of their domestic firms have built up competitive advantages for international production as well through outward FDI, at least in neighboring countries at similar levels of development. In 2011-2013, average annual flows of FDI from the LDCs amounted to US\$ 4.5 billion, nearly nineteen times those in 2001-2003. ${ }^{17}$ African LDCs, led by Angola (US\$ 2.3 billion) and Liberia (US\$ 0.8 billion), accounted for most of the outflows. ${ }^{18}$ Although these outflows are very unevenly distributed among the home economies, this is a phenomenon that deserves attention, including from policy-makers.

\section{Policies, programmes and measures to stimulate FDI flows to the LDCs and increase host-country benefits: A stock-taking}

\subsection{Host-country policies, programmes and measures}

The LDCs have been making strong efforts to attract increased FDI flows and enhance the benefits for their economies. They are liberalizing their national policies with respect to inward FDI and, in several cases, provide fiscal and other incentives to foreign investors. Many have entered into bilateral, regional and other international investment agreements and double taxation treaties. Most of them have established investment promotion agencies or other institutions that can play an active role in attracting FDI by

\footnotetext{
${ }^{16}$ UNCTAD, World Investment Report 2013, op. cit., pp. 50-51, and Julia Kubny and Hinrich Voss, "The impact of Chinese outward investment: Evidence from Cambodia and Vietnam" (German Development Institute, Discussion Paper 16/2010), available at http://www.eu-china.net/web/cms/upload/pdf/materialen/11-03-

02_Impact\%20of\%20Chinese\%20outward\%20investment.pdf (last visited 18 June 2014).

${ }^{17}$ Based on the data on outward FDI flows in the annex table.

${ }^{18}$ Outward FDI projects from Angola are reported to have been mainly in the coal, oil and gas industries (see, WESGRO (The Western Cape Destination Marketing, Investment and Trade Promotion Agency, South Africa), “Angola: Country fact sheet," available at 2013.05 Angola_FS.pdf_Adobe Reader (last visited August 24, 2014)). Information on the destination industries for outward FDI from Liberia could not be obtained.
} 
providing information to, and assisting, foreign investors, and they are taking steps to improve the overall environment for business. At the same time, as in several other developing countries, the dominant trend towards liberalizing and promoting investment has been accompanied by a move towards fostering a regulatory framework for investment in general, and FDI more specifically, that takes countries' particular development goals and concerns into account, generally through industry-specific restrictions and conditions, incentives and targeted promotional efforts.

\subsubsection{National policy framework}

Most of the LDCs are now open to FDI in a wide range of activities, as indicated by their laws and regulations. ${ }^{19}$ There are, however, a number of specific prohibitions and restrictions imposed by countries. For example, in Sudan, there are restrictions on foreign investment in transportation, media and communications, electricity, and financial services; some industries (railway freight transportation, airport operation, newspaper publishing) are closed to foreign participation. ${ }^{20}$ In Bangladesh, investors in natural resources and infrastructure, including power, mineral resources and telecommunications, must seek approval from the relevant government ministries. In South Sudan, companies with less than seven employees are reserved for national owners and medium-size and large private companies are required to have at least 31 per cent national ownership. In Cambodia, all sectors are open to foreign investment and $100 \%$ foreign ownership is permitted in most, but in a few, including cigarettes, movies, rice milling, gemstone mining and processing, publishing and printing, radio and television, wood and stone carving, and silk weaving, foreign investment is subject to conditions, local equity participation or prior authorization. In Haiti, foreign investors are permitted 100 per cent ownership of companies and can enter into joint ventures of any kind with Haitian citizens, but the sale and purchase of company shares are regulated by the state.

In several LDCs, foreign enterprises receive treatment no less favourable to that provided to national domestic enterprises. Examples of countries providing national treatment include Afghanistan, Burkina Faso, Burundi, Mali, Mozambique, Niger, Sao Tome and Principe, Senegal, and Zambia. There are some exceptions, however, as in the case of land ownership. For example, in Benin, Cambodia, Equatorial Guinea, Lao PDR, Liberia, Myanmar, and Rwanda, foreign investors are not permitted to own land -- but they can lease it from others.

Fiscal and other incentives are provided to foreign investors in several LDCs. Bangladesh, for example, offers foreign investors tax holidays and exemptions, reduced import duties on capital goods, machinery and spare parts and duty-free imports for $100 \%$ exporters of ready-made garments. In Haiti, investment that provides added value of at least 35 per cent in the processing of local or imported raw material are eligible for customs, tax and other advantages. Sudan's new Investment Act 2013 offers tax and customs

\footnotetext{
${ }^{19}$ Most of the LDCs have adopted laws relating to FDI and some have revised their investment legislation. The ones to do so most recently are Lao Peoples Democratic Republic (Investment Promotion Law, 2009), South Sudan (Investment Promotion Act, 2009), Liberia (Investment Act, 2010), Timor-Leste (Private Investment Law, 2011), Malawi (Investment and Export Promotion Act, 2012), Myanmar (Foreign Investment Law, 2012, and rules, 2013), and Sudan (Investment Act 2013).

${ }^{20}$ Unless otherwise indicated, the information in this section on the provisions in LDCs' national laws and regulations relating to FDI is from United States Department of State, Bureau of Economic and Business Affairs, "Investment climate statements 2013," available at http://www.state.gov.e/eb/rls/othr/ics/2013/index.htm (last visited 1 May 2014).
} 
privileges to investors in strategic industries. ${ }^{21}$ Other examples of countries that have introduced tax incentives include Burundi, Malawi, Sao Tome and Principe, and Zambia. ${ }^{22}$

At the same time, some of the LDCs impose conditions on foreign investors when considered desirable from a national development perspective. For example, under a new foreign exchange law in force from October 2012, Angola requires oil TNCs operating in the country to use local banks (including affiliates of foreign banks) to pay their taxes and make payments to foreign suppliers and subcontractors. ${ }^{23}$ The objective is to strengthen the development of the national banking system, which has already grown considerably, partly due to FDI in the industry.

\subsubsection{International framework}

At the international level, many LDCs have entered into bilateral investment treaties (BITs) that generally provide for national treatment, most-favoured-nation treatment and fair and equitable treatment of investors, nationalization only under specific conditions, and unrestricted transfers of capital and earnings. The number of such treaties has risen steadily since the mid-1990s. ${ }^{24}$ As of June 2013, all but six of the LDCs had signed one or more BITs, with Bangladesh (29 BITs), Mozambique (24), Senegal (24), Ethiopia (29), Sudan (27), and Yemen (37) having the largest number of such treaties. ${ }^{25}$

Most of the LDCs have also made provisions - typically through BITs -- for the resolution of disputes with foreign investors. A majority (37) of them are members of the International Centre for Settlement of Investment Disputes (ICSID). Several are open to dispute settlement under the United Nations Commission on International Trade Law, and several have adhered to the Convention on the Recognition and Enforcement of Foreign Arbitral Awards. Some are members of other international dispute settlement mechanisms, such as the Organization for the Harmonization of African Business Law (OHADA): Benin, for example, is a member of OHADA and has adopted OHADA's universal commercial code to manage commercial disputes and bankruptcies. Benin is also a member if OHADA's Common Court of Justice and of ICSID.

Furthermore, most LDCs are party to one or more regional economic agreement with FDI provisions. ${ }^{26}$ In the African region, such agreements include the Common Market for Eastern and Southern Africa, the Southern Africa Development Community, the Economic Community of West Africa, and the West Africa Economic and Monetary Union. In Asia and the Pacific, regional agreements include the ASEAN Comprehensive Investment Agreement and the ASEAN-China Investment Agreement. The South Asian Association for Regional Cooperation is in the process of finalizing the text of the draft SAARC

\footnotetext{
${ }^{21}$ UNCTAD, World Investment Report 2013, op. cit., p. 94.

${ }^{22}$ UNCTAD, Foreign Direct Investment in the LDCs, op. cit., p. 15.

${ }^{23}$ Ibid., p. 77.

${ }^{24}$ Ibid., p. 17.

${ }^{25}$ UNCTAD, "Country-specific lists of BITs," available at http://unctad.org/en/Pages/DIAE/International\%20Investment\%20Agreements\%20(IIA)/Country-specific-Lists-of-BITs.aspx (last visited 25 June 2014).

${ }^{26}$ While such agreements, as well as BITs, may not matter much where FDI is accompanied by contractual arrangements, they may be useful in other cases.
} 
Agreement on Promotion and Protection of Investment ${ }^{27}$. Haiti is a member of the Caribbean Community, which brings together 15 states in the Caribbean into a single market and economy.

At the inter-regional level, 40 LDCs are members of the Partnership Agreement between the members of the African, Caribbean, and Pacific (ACP) States on the one side and the European Union (EU) on the other (the Cotonou Agreement). ${ }^{28}$ The agreement provides, among others, for financial cooperation measures that the ACP States and the European Community and its member states should put in place to promote investment and "encourage the EU private sector to invest and to provide specific assistance to its counterparts in the ACP countries under mutual cooperation and partnerships," ${ }^{29}$ and disseminate information on investment opportunities and business operating conditions in the ACP states. It calls for financial support to investors, investment guarantees and investment protection. The agreement has also established a joint EU-ACP institution, the Centre for the Development of Enterprise, with the objectives of assisting investment promotion activities, the facilitation of business cooperation between EU and ACP enterprises and the dissemination of information about business opportunities for EU companies in ACP countries.

At the multilateral level, many of the LDCs are parties to the General Agreement on Trade in Services (GATS), which is relevant for FDI in services, and the agreements on Trade-related Investment Measures (TRIMs) and Trade-related Aspects of Intellectual Property Rights (TRIPS). However, their GATS commitments are often minimal, presumably due to a desire to maintain adequate policy space in the services sector. ${ }^{30}$ A majority of the LDCs are also members of the World Bank's Multilateral Investment Guarantee Agency (MIGA). Nearly all are members of the International Labour Organisation (ILO), so that they are in principle committed to respecting, promoting and realizing the principles and rights that are the subject of the ILO Declaration and Convention on Fundamental Principles and Rights at Work.

LDCs have also entered into double taxation treaties, mainly with respect to taxes on income and capital: Yemen (37), Bangladesh (27), Sudan (27), United Republic of Tanzania (17), Senegal (14), and Zambia (12) had the largest number of such treaties as of June $2011 .^{31}$

27 The SAARC Standing Committee, at its Forty-first Session (Kathmandu, 23-24 November 2014), urged early finalization of the text of the SAARC Agreement on Promotion and Protection of Investment ("Note by the Secretariat on Economic and Financial Co-operation (as on 22 January 2015)," available at: http://www.saarc-sec.org (last visited 25 March 2015).

${ }^{28}$ The Cotonou Agreement was signed in Cotonou, Benin, on 30 June 2000. It replaced the Lome Convention that had hitherto laid down the framework for economic cooperation between the EU and the ACP states. It was revised in Luxembourg on 25 June 2005 and again in Ougadougou on 22 June 2010. (European Commission, Development and Cooperation- Europeaid, "The Cotonou Agreement," available at http://ec.europa.eu/europeaid/where/acp/overview/cotonou-agreement/index_en.htm (last visited 25 June 2014)).

${ }^{29}$ European Commission, The Cotonou Agreement: 2010 Consolidated Version, chapter 7, article 75, "Investment promotion," available at http://ec.europa.eu/europeaid/where/acp/overview/cotonou-agreement/index_en.htm (last visited 25 June 2014).

${ }^{30}$ Dale Honeck, ““"Expect the unexpected”: LDC GATS commitments as internationally credible policy indicators? - the example of Mali," Staff Working Paper ERSD-2011-07, World Trade Organization, 19 May 2011, available at http://www.wto.org/english/res_e/ersd201107_e.pdf (last visited 25 June 2014). Participation in the TRIMs and TRIPS agreements could involve the imposition of significant restrictions on the use of performance measures and subsidies.

31 UNCTAD, "Country-specific lists of double-taxation treaties," available at http://unctad.org/en/Pages/DIAE/International\%20Investment\%20Agreements\%20(IIA)/Country-specific-Lists-of-DTTs.aspx (last visited 25 June 2014). 


\subsubsection{Investment promotion and facilitation}

The LDCs have recognized the importance of promoting and facilitating FDI by providing foreign investors and potential investors with information and assistance. Many of them have established investment promotion agencies (IPAs) for that purpose, while some countries have entrusted the task to Boards of Investment or specific ministries or government departments. As of 2011, 31 LDCs had such agencies or other institutions, and 29 of those national investment promotion bodies were members of the World Association of Investment Promotion Agencies. ${ }^{32}$ In some cases, as for example in Afghanistan, Mali and Uganda, ${ }^{33}$ they serve as one-stop shops for investors.

Successful promotion of FDI also requires that the rules and regulations faced by and the procedures required of investors and business in general be easy to navigate, and the costs of doing business be relatively low. In this respect, only a few of the LDCs have made noticeable advances thus far. According to the World Bank's 2014 Doing Business rankings of countries, only one of the LDCs, Rwanda, with a rank of 32, was among the top 50 in the world, and only four others - Samoa (61), Solomon Islands (97), Vanuatu (74), and Zambia (83) -- ranked among the top $100{ }^{34}$ A majority (26 countries) had rankings ranging between 154 and 179. Rwanda's relatively high position in the 2014 ranking reflects the fact that the country has made more progress than any other on the doing business indicators since 2006, with its overall performance relative to the frontier (of 100, indicating best performance) rising from 37 to $54 .{ }^{35}$ Other LDCs with considerable improvements relative to the overall performance frontier since 2006 include Burkina Faso, Liberia, Burundi, Mali, and Sierra Leone.

Investment promotion has been found to have a positive impact on FDI flows to developing countries (but not in industrialized countries), and to work better in places with higher information asymmetries and bureaucratic red tape. ${ }^{36}$ That suggests that investment promotion can play an important role in attracting FDI to the LDCs, where lack of information can be a major constraint for foreign investors, although there are costs involved in such promotion that make a cost-benefit analysis of promotional activities desirable. In addition to establishing IPAs, some LDCs are participating in the development of on-line investment guides (i-guides) as part of a joint project by UNCTAD and the International Chamber of Commerce. As of 2014, such guides have been published for eight LDCs, and in seven of them there was an approximate increase in FDI inflows of between up to two-fold to ten-fold between the four-year period following the publication of the Guides and the preceding four-year period. ${ }^{37}$

\footnotetext{
${ }^{32}$ UNCTAD, Foreign Direct Investment in LDCs, op. cit., Part Two: "Investment Profiles".

${ }^{33}$ Ibid, annex table 15 , p. 59.

${ }^{34}$ The World Bank, available at http://www.doingbusiness.org/custom-query (last visited 25 June 2014). The rankings cited refer to overall ranking, which is based on rankings with respect to 10 items: starting a business; dealing with construction permits; getting electricity; registering property; getting credit; protecting investors; paying taxes; trading across borders; enforcing contracts; and resolving insolvency. The overall measure of performance relative to the frontier - which represents the best performance among all of the countries -- excludes performance with respect to getting electricity.

${ }^{35}$ The World Bank, available at http://www.doingbusiness.org/data/distance\%20to\%20frontier (last visited 25 June 2014).

${ }^{36}$ Torfinn Harding and Beata Smarzynska Javorcik, "Roll out the red carpet and they will come: investment promotion and FDI inflows", Working Paper, Department of Economics, University of Warwick, Coventry, UK (CAGE Online Working Paper Series), June 2010, No.18, Permanent WRAP: http://wrap.warwick.ac.uk/57330 (last visited 25 June 2014).

${ }^{37}$ UNCTAD, Division on Investment and Enterprise: Results and Impact Report, 2014, Draft Advance Copy, p. 32, available at www.unctad.org/en/PublicationsLibrary/diae2014d2_en.pdf (last visited 19 May 2014).
} 
Policy Options for Promoting FDI in the LDCs

\subsection{Home-country policies, programmes and measures}

It is not only host LDCs that can take steps to increase FDI flows to their economies and maximize the benefits from them, but home countries can take actions as well. All developed countries implement, to some degree, policies, programmes and measures to encourage outward FDI flows, and some developing countries and economies in transition have also begun to do so. Such home-country measures are often directed towards encouraging FDI flows to developing countries in general, and some of them are particularly relevant for stimulating FDI flows to, and increasing their benefits for, the LDCs.

\subsubsection{National policies and international arrangements with respect to outward FDI}

Virtually all developed countries today have liberal policies with respect to outward FDI, allowing their firms to invest freely abroad, with few restrictions. The restrictions that remain are based largely on political or national security considerations. Several developing countries and economies in transition have also liberalized their outward FDI policies, while others are still in the process of gradually relaxing their restrictions on outward FDI ${ }^{38}$ Furthermore, some developed as well as emerging home countries have adopted an FDI-cum-ODA/economic cooperation approach to direct investment abroad, combining FDI by their firms in some projects, such as resource-seeking ones, with economic cooperation involving home governments. ${ }^{39}$

Moreover, virtually all developed countries as well as the great majority of developing home countries have entered into bilateral investment treaties (BITs) with LDCs, meant to help LDCs attract FDI by protecting the investment of the respective home countries' firms in host countries and facilitating their operations there. As of 1 June 2013, the top 10 developed home countries in terms of total outward FDI flows in 2007-2011 had concluded 128 BITs with LDCs, while the top ten developing and transition home economies had concluded 53 BITs with LDCs. ${ }^{40}$

\subsubsection{Measures to facilitate, support and promote outward FDI}

While liberal outward FDI regimes and participation in international agreements ${ }^{41}$ create an environment conducive to FDI by a country's firms, the actual amount of such investment can be influenced considerably by home country measures that directly assist outward investors. Such measures are often intended to advance a home country's strategic economic interests and enhance the international

\footnotetext{
${ }^{38}$ Information on outward investment regulations in 83 countries, as of 2011, is provided in Karl P. Sauvant, Persephone Economou, Ksenia Gal, Shawn Lim, and Witold P. Wilinski, "Trends in FDI, home country measures, and competitive neutrality," in Andrea K. Bjorklund, ed., Yearbook on International Investment Law and Policy 2012-2013 (New York: Oxford University Press, 2014), chapter 1 . The discussion of home country measures below is based on the findings of this publication.

${ }^{39}$ It has been noted that Japan, and more recently China, provide examples of such "resource-seeking diplomacy". See Terutomo Ozawa, "Explaining the rise of East Asian multinationals: State-industry links, a stages-model of structural change, and Japan as a precedent setter", in The Evolution of the World Economy: The "Flying-Geese" Theory of Multinational Corporations and Structural Transformation (Cheltenham, Glos., U.K.: Edward Elgar, forthcoming).

${ }^{40}$ For the list of top home economies, see Sauvant et al., op.cit., table 4; the data on BITs are based on UNCTAD's IIA data-base, available at http://unctad.org/en/Pages/DIAE/International\%20Investment\%20Agreements\%20(IIA)/Country-specific-Lists-ofBITs.aspx (last visited 28 April 2014).

${ }^{41}$ The question to what extent international investment agreements lead to more FDI is hotly debated. For a collection of studies on this subject, see Karl P Sauvant and Lisa E. Sachs, eds., The Effect of Treaties on Foreign Direct Investment: Bilateral Investment Treaties, Double Taxation Treaties, and Investment Flows (New York: OUP, 2009).
} 
competitiveness of its firms by helping them establish a portfolio of locational assets; but part of the reason for such measures is also to encourage FDI flows to developing countries and to assist the latter in their economic development, as a complement to their efforts to attract FDI. To the extent that such measures, discussed below, are applied to investment in LDCs, they can increase FDI flows to, and their benefits for, LDCs.

Home country measures involve the granting of specific advantages by a home country government (or one or more of its public institutions) in connection with the establishment, acquisition or expansion of an investment by a home country firm in a foreign economy. ${ }^{42}$ All developed countries, as well as some developing economies and economies in transition, have established or designated institutions that implement such measures. ${ }^{43}$ They include, among others, government departments or ministries, investment promotion agencies, export-credit agencies, development finance institutions, investment/trade promotion agencies at the national or local levels and their foreign offices, and private organizations fulfilling government mandates.

The most important direct measures used by governments to facilitate, support and promote outward FDI are the following:

- Information services include the provision of data on the economic and legal investment climate, the political environment and business opportunities in host countries; information on the benefits of internationalization and on the legal and economic aspects of international expansion; and the provision of relevant statistics. Other support services include advice and consulting; investment missions; match-making services, including contacts with governments and entrepreneurs in host countries and maintaining matchmaking data bases; and training and educational services related to outward FDI.

- Financial measures include grants for activities such as feasibility studies and other preinvestment activities; assisting with the costs of setting up overseas offices; training of staff for employment in foreign affiliates; executive programmes for managers; and customized training programmes. They also include loans (concessional and non-concessional), structured financing options, public-private/public-public risk-sharing arrangements, and development financing. Other financial measures include equity participation, direct or as development financing.

- Fiscal measures include tax exemptions of various kinds (e.g., exemption from corporate income tax on certain incomes), deduction for qualifying expenditures; corporate tax relief; tax deferral for incomes earned overseas; and tax credits for certain kinds of expenditure.

- Political-risk insurance includes a range of insurance products covering expropriation, war damage, political violence, conversion of local currency or its transfer out of the host country, the suspension of remittances, and forced abandonment of assets abroad by home-country investors. It is intended to mitigate risks associated with investing abroad and generally requires the payment of a premium.

\footnotetext{
42 Ibid.

${ }^{43}$ The 20 top home economies examined in Sauvant et al. op. cit., had a combined total of more than 50 national institutions involved in providing support to outward FDI.
} 
Direct assistance through the measures listed above assumes greater importance for encouraging FDI in the LDCs than in other countries. In particular, information and knowledge gaps with respect to available opportunities and host-country conditions are likely to be greater in the case of the former, and the need for political risk insurance is more acute.

\subsubsection{Eligibility conditions for direct support through home-country measures}

In many countries, the measures for direct support described above are not offered uniformly to all outward investors. Factors such as the sector or industry in which an investment is made; the size of the investing firm; destination; and effects of outward FDI on host countries; are taken into account to determine whether an investor qualifies for assistance. Some of the conditions used can work to affect FDI flows to LDCs positively. For example, preferential support to FDI in natural resources can increase flows to the LDCs, in many of which extractive industries are the main attraction for FDI.

- Sector or industry. Although there are no stringent sectoral or industrial limitations on support/assistance to outward investors from home country institutions, a number of them specify sectors and industries for support. They typically include natural resources, energy and infrastructure. The emphasis on assistance to outward FDI in natural resources is of relevance to stimulating FDI in several LDCs, while that on assistance to FDI in energy and infrastructure is important for the LDCs generally, as they are in particular need of such investment in order to improve production capacity and accelerate growth.

- Size. Many home countries give additional preferential support to FDI by their small and mediumsize enterprises (SMEs). Examples include the special financing lines and funds offered to SMEs by the Spanish financing corporations Compania Espanola de Financiacion de Dessarrollo (COFIDES) and the Instituto Credito Official and the preferential treatment offered to SMEs by the United States' Overseas Private Investment Corporation (OPIC) under certain conditions. ${ }^{44}$ Such support is likely to be of particular importance for promoting FDI in the LDCs, which, given their relatively small markets and limited supply of skills and human capital, are more likely to attract FDI by SMEs rather than by large firms, except in natural resources where production is primarily for export.

- Destination. Most home country measures are available to firms regardless of the destination of their FDI. However, a number of them encourage investment in specific destinations. Many developed countries have specialized agencies to provide long-term financing for private-sector development in developing and transition economies by providing loan and equity financing for FDI projects in those countries, sometimes by taking minority equity positions. ${ }^{45}$ The mission of the United States' OPIC, for example, is to mobilize and facilitate the participation of United States private capital and skills in the economic and social development of developing countries

\footnotetext{
${ }^{44}$ OPIC, "Doing business with us: Small business sector," available at http://www.opic.gov/doing-business-us/small-businesscenter. In 2012, the share of projects involving United States small businesses accounted for 73\% of OPIC's total commitments (OPIC, 2012 Annual Report, available at http://www.opic.gov/sites/default/files/files/OPIC_2012_Final.pdf (last visited 25 June 2014).

${ }^{45}$ UNCTAD, World Investment Report 2003: FDI Policies for Development. National and International Perspectives (Geneva: United Nations, 2003), p. 158.
} 
and economies in transition, to complement the development assistance objectives of the United States. OPIC's main instruments are medium to long-term financing and the provision of political risk insurance. OPIC has been strengthening its focus on FDI in the developing countries most in need of increased investment and transfer of technology, including the LDCs. ${ }^{46}$ Germany's development finance agency, Deutsche Investitions und Entwicklungsgesellschaft mbh (DEG), is placing growing emphasis on assisting investments in Africa, including in sub-Saharan Africa. ${ }^{47}$

Some home country measures cater specifically to FDI in certain geographic regions, in pursuit of national strategies. For example, the China-Africa Development Fund, established by the Government of China in 2006, provides support for Chinese enterprises investing in Africa, generally by taking a minority share in vetted projects, with an expectation of a profitable return on exit. Although such support is one of many tools, including among others direct financial support by China's Ministry of Finance and related banks, since its establishment, Chinese FDI in Africa has grown rapidly, rising from an average of US\$ 410 million per year during 2004-2006 to US\$ 3 billion per year during 2010-2012, with flows to sub-Saharan Africa comprising US\$ 2.6 billion. ${ }^{48}$ The LDCs Angola, Democratic Republic of Congo, Equatorial Guinea, Ethiopia, and Zambia figure among the top sub-Saharan host countries for Chinese FDI in 2010-2012.

- Effects of outward FDI. Home countries may also make their support to outward investment conditional on its effects on the home and/or host countries. It may require positive development impacts on the host country, in terms, for example, of job creation, infrastructure improvements and technology and knowledge transfer. Firms may also need to provide environmental and social impact assessments or meet certain corporate responsibility standards. For example, eligibility for support from the United States' OPIC requires that a project meet the workers' rights standards of the International Labour Organization, including the right to unionize, collective bargaining, minimum age requirements, and a prohibition on forced labour. ${ }^{49}$ Similarly, the Japan Bank for International Cooperation conducts a review of environmental and social conditions when making a decision on funding, and conducts monitoring and follow-up after the decision has been made. ${ }^{50}$ Such conditionality and follow-up are of particular importance for improving host-country benefits from FDI in the LDCs, where local capabilities for negotiating favourable conditions with foreign investors and monitoring the impacts of FDI are likely to be limited.

\subsubsection{Indirect measures by home countries}

In addition to the direct measures discussed above, home countries may pursue measures that are not

\footnotetext{
${ }^{46}$ In 2012, total commitments by OPIC to projects in low-income countries were US\$1.00 billion, and to projects in sub-Saharan Africa, US\$ 907 million, out of a total portfolio of US\$ 16.4 billion) (OPIC, 2012 Annual Report, op. cit.).

47 DEG, Annual Report 2012, p. 17, available at https://www.deginvest.de/DEG-deutsche-Dokumente/PDFs-DownloadCenter/DEG_Annual_Report_2012.pdf (last visited 25 June 2014). DEG's financial commitments for 2012 were spread over 40 countries; the LDCs in which funds were made available were Ethiopia, Bangladesh and Uganda.

${ }^{48}$ Based on data from UNCTAD, Bilateral FDI Statistics, 2014 (Geneva: United Nations, 2014), available at http://unctad.org/en/Pages/DIAE/FDI\%20Statistics/FDI-Statistics-Bilateral.aspx (last visited 25 June 2014).

${ }^{49}$ OPIC, “Our investor screener," available at http://www.opic.gov/doing-business-us/our-investor-screener (last visited 25 June 2014).

${ }^{50}$ JBIC, "Guidelines for confirmation of environmental and social considerations," April 2012, available at https://www.jbic.go.jp/wp-content/uploads/page/efforts/environment/confirm_en/pdf_01.pdf (last visited 25 June 2014 ), p. 4.
} 
targeted specifically at outward FDI but nonetheless influence it. For example, ODA for infrastructure projects in LDCs may make the countries more attractive to FDI. Such ODA can also lead directly to FDI projects from the donor country, as is the case when donor governments provide finance in conjunction with outward FDI by their firms. ${ }^{51}$

Policy measures expanding access to a home country's markets may also indirectly encourage FDI flows from that country as well as others to the countries that enjoy improved access for their exports. One example of such measures is the Africa Growth and Opportunity Act (AGOA) of the United States, which provides preferential access to the United States market for imports from designated sub-Saharan countries (39 countries, as of 2013). ${ }^{52}$ Another is the European Union's Everything-but-Arms arrangement under which all LDCs receive duty-free and quota-free access to EU markets for their exports, with the exception of arms and ammunition.

\subsection{Schemes and programmes implemented by international organizations}

Host and home country efforts to boost FDI flows to, and its benefits for, the LDCs are supported and supplemented by schemes and programmes implemented by international and regional organizations. In this context, the work of the United Nations Conference on Trade and Development (UNCTAD); the United Nations Industrial Development Organization (UNIDO); the Multilateral Investment Guarantee Agency (MIGA), the World Bank, and the International Finance Corporation (IFC) (all members of the World Bank Group); and the International Labour Organization are of particular importance.

UNCTAD is one of the few organizations that undertakes activities directly focused on FDI in LDCs. In particular, its Investment Advisory Council for LDCs, created in 2001 in collaboration with the International Chamber of Commerce, provides senior business executives and senior government officials with an informal and flexible framework for discussing practical ways of attracting FDI and benefiting from it. The 11th meeting of the Council took place during the 2014 World Investment Forum in Geneva (13-16 October 2014). ${ }^{53}$ This work, in turn, relies partly on UNCTAD's statistical work, in the framework of which the Organization has issued from time to time FDI country profiles that, in a succinct manner, summarize key FDI statistics for each LDC - the most comprehensive publication of its kind. ${ }^{54}$ Moreover,

\footnotetext{
${ }^{51}$ Some of the infrastructure projects recently supported by China, such as the Sicomines project in the Democratic Republic of Congo, may fall into this category. See Johanna Jansson, Christopher Burke and Wentan Jian, "Chinese practices at extractive industries of Gabon and the DRC: perceptions of transparency," Centre for Chinese Studies, University of Stellenboch, 2009, available at http://www.ccs.org.za/wp-

content/uploads/2009/11/Chinese_Companies_in_the_Extractive_Industries_of_Gabon_and_the_DRC.CCS_report_August_200 9.pdf (last visited 25 June 2014).

${ }^{52}$ AGOA was signed into law on May 18, 2000, as Title 1 of the United States' Trade and Development Act of 2000. It was amended on August 6, 2002 (AGOA 2) and July 12, 2004 (AGOA 3). The Africa Investment Incentive Act of December 20, 2006 further amended portions of AGOA (AGOA 4). See, http://trade.gov/agoa/legislation/agoa4.asp (last visited 25 June 2014).

${ }^{53}$ The World Investment Forum, organised by UNCTAD, is "a high-level biennial multi-stakeholder gathering designed to facilitate dialogue and action on the world's key emerging investment-related challenges. Its mission is to provide a platform where a debate on investment for development can take place and ultimately to promote

Investment flows that contribute to sustainable and inclusive development." (UNCTAD, available at http://unctadworldinvestmentforum.org/about-wif-2014/ (last visited 25 June 2014)).

${ }^{54}$ For the latest profiles for the LDCs, see UNCTAD, Foreign Direct Investment in LDCs, op. cit., Part Two, Investment Profiles, pp. 62-228.
} 
UNCTAD's flagship publication, the World Investment Report, contains (since 2011) a special section analyzing FDI trends in the LDCs. ${ }^{55}$

Given the weak statistical systems available to collect FDI and TNCs data in most LDCs, UNCTAD has been undertaking a project aimed at enhancing the capacity of government agencies as regards the compilation of such data. The project is implemented for a number of countries in collaboration with regional groups such as the Common Market for Eastern and Southern Africa and the Association of Southeast Asian Nations (ASEAN), as well as with other international organizations such as IMF. UNCTAD has so far organized a dozen national workshops in the following LDCs: Burundi, Comoros, Djibouti, Democratic Republic of the Congo, Ethiopia, Malawi, Myanmar, Rwanda, Sudan, Uganda, United Republic of Tanzania, and Zambia.

In the context of its broader advisory work, UNCTAD offers advice on the improvement of national investment laws and models for international agreements, based on its Investment Policy Framework for Sustainable Development ${ }^{56}$ and its extensive work monitoring FDI trends and policies and analyzing FDI's implications for development. (Relevant is here also UNCTAD's work based on the Principles for Responsible Agricultural Investment. ${ }^{57}$ ) Particularly important are also the investment policy reviews (IPRs) for developing countries and technical assistance in the implementation of recommendations made in the reviews and accepted by the countries concerned. As of June 2014, 17 out of the 36 country IPRs prepared since the inception of the programme (in 1999) have focused on LDCs, including Bangladesh, Benin, Burkina Faso, Burundi, Democratic Republic of Congo, Djibouti, Ethiopia, Haiti, Lesotho, Malawi, Mauritania, Mozambique, Rwanda, Sierra Leone, Uganda, United Republic of Tanzania, and Zambia. One benchmark of the impact of UNCTAD's IPRs is the extent to which governments find the recommendations useful and the rate at which they are implemented. The implementation reports prepared by UNCTAD up to 2013, which covered, among others, the LDCs Ethiopia, Lesotho, Rwanda, United Republic of Tanzania and Uganda, showed, on average, a good to strong implementation record, growing interest by existing investors and increased capacity to market investment opportunities. ${ }^{58}$ The implementation of the recommendations led, among other things, to the creation of an investment promotion agency in Burundi, the establishment of the Presidential Council on Investment in Burkina Faso and the adoption of a skills attraction and dissemination programme in Rwanda.

This work, in turn, is closely linked with UNCTAD's advisory services relating to investment promotion, which includes the dissemination of practical advice and case studies of best practice in investment promotion among IPAs in developing countries, including the LDCs, and international organizations of IPAs, including the World Association of Investment Promotion Agencies (WAIPA - in which most LDCs are members). ${ }^{59}$ The outcomes of such dissemination include the use of the guides by national IPAs

\footnotetext{
${ }^{55}$ See UNCTAD, World Investment Report 2013, op. cit., pp. 73-77.

56 See UNCTAD, World Investment Report 2012: Towards a New Generation of Investment Policies (Geneva: United Nations, 2012), pp. 104-108, available at http://unctad.org/en/PublicationsLibrary/wir2012_embargoed_en.pdf (last visited 25 June 2014).

${ }^{57}$ See, UNCTAD, Division on Investment and Enterprise: Results and Impact Report 2014, draft advance copy, pp. 34-35, available at http://unctad.org/en/PublicationsLibrary/diae2014d2_en.pdf (last visited 25 June 2014). The principles for Responsible Agricultural Investment have been developed by UNCTAD jointly with the United Nations Food and Agriculture Organization, the International Fund for Agricultural Development, and the World Bank.

${ }^{58}$ UNCTAD, ibid., p. 22.

${ }^{59}$ UNCTAD, ibid., p. 31.
} 
for their strategies and functional structure, as well as for their in-house training activities, and by WAIPA for their international training programmes for member IPAs. UNCTAD's advisory services also include the publication of investment guides in the form of i-guides, an activity in which, as noted above (in section 2a) several LDCs are participants as well as beneficiaries.

Other international organizations, too, undertake activities that are immediately relevant to FDI in LDCs, in the broader context of activities for groups of developing countries or all of them.

Thus, UNIDO focuses much of its work on FDI in the LDCs on the Africa Investment Promotion Agency Network (AfrIPAnet). Now covering 38 states, many of which are LDCs, it is a forum for African governments to discuss investment promotion strategies. It includes an investment-monitoring platform, which is a tool for analysis of investment data, currently covering 19 African countries, including 14 LDCs. ${ }^{60}$ UNIDO also works with countries to improve their regulatory environments to promote business and investment and to strengthen the development impact of FDI, including through partnerships with TNCs. ${ }^{61}$ For example, the Organization is working with technology providers Scania and Volvo on skill development in agricultural machinery in Iraq and Ethiopia, respectively, by establishing and upgrading local industrial training academies; with market access providers Metro and AEON on facilitating sourcing from suppliers in LDCs and addressing conformity assessment issues; and, more recently, with DNV GL Business Assurance on measuring the water footprint in the textile industry. Such joint programmes allow companies to participate in the work-force development of their host countries, increasing the potential benefits of future investments.

The Word Bank Group undertakes a wide range of activities that are of immediate relevance to FDI and LDCs, typically undertaken in the framework of activities geared to differently defined groups of countries. Thus, one of MIGA's priorities is to encourage FDI into the world's poorest economies,${ }^{62}$ by providing political risk insurance to investors. ${ }^{63}$ Political risk, including risks relating to factors such as currency-convertibility and funds-transfer restrictions, expropriation and war, ranks high among the constraints to foreign investment in developing countries, including the LDCs. For example, in 2010, 2011 and 2012, political risk was ranked at the top of the most important constraints for FDI in developing countries (including LDCs) in a MIGA-EIU survey of foreign investors' views. ${ }^{64}$ (In the 2013 survey, macro-economic instability was, for the first time, the leading constraint, but political risk remained a major concern. ${ }^{65}$ ) MIGA complements public and private sources of investment insurance against political risks in developing countries, including the least developed among them. Investment guarantees provided by MIGA require compliance with a comprehensive set of environmental and social performance

\footnotetext{
${ }^{60} \mathrm{See}$, http://www.unido.org/en/what-we-do/cross-cutting-issues/least-developed-countries.html (last visited 25 June 2014).

${ }^{61} \mathrm{See}$, http://www.unido.org/fileadmin/user_media/Services/PSD/UNIDO_business_partnerships/UNIDO_BPP_English_2013.pdf last visited 25 June 2014).

${ }^{62}$ Namely, members of the International Development Association.

${ }^{63}$ MIGA, Annual Report, 2012, available at www.miga.org/documents/AR2012_English.pdf (last visited 25 June 2014). For a detailed discussion, see, MIGA, World Investment and Political Risk 2013 (Washington, D.C.: MIGA, 2013), DOI:10.1596/9784648-0039-9 License: Creative Commons Attribution CC BY 3.0, available at http://www.miga.org/documents/WIPR13.pdf (last visited 25 June 2014).

${ }^{64}$ MIGA, World Investment and Political Risk 2013, op. cit., table 1, p. 7.

${ }^{65}$ MIGA, World Investment and Political Risk 2013, op. cit., table 1, p. 7.
} 
standards. ${ }^{66}$ One group of firms that is particularly sensitive to political risk are SMEs. MIGA's Small Investment Programme (launched in 2005) provides such insurance at discounted premiums, to facilitate investments into small and medium-size enterprises involved in finance, agribusiness, manufacturing, and services. This programme is of special relevance to LDCs, as FDI there, especially in manufacturing and services, is more likely to flow into smaller enterprises. ${ }^{67}$

MIGA also places a strategic focus on investments in 36 conflict-affected and fragile economies, 24 of which were LDCs at the beginning of $2014 .{ }^{68}$ For that purpose, MIGA launched (in June 2013) the Conflict Affected and Fragile Economies Facility. In addition to MIGA guarantees, the Facility uses donor contributions and guarantees to provide an initial loss layer to insure investment projects in fragile and conflict contexts. ${ }^{69}$

This work is complemented by the IFC's projects to manage grievances of investors vis-à-vis their host countries and, if these should occur, to seek to resolve them through alternative dispute-settlement mechanisms. (The investor-grievance management project is discussed below.) Its Investment Advisory Services partner with local governments, justice ministries, lawyers associations, business organizations, and donors to address the needs of the private sector in dispute resolution and assist client countries to develop alternative dispute-settlement mechanisms, including in six LDCs (Bangladesh, Burkina Faso, Cambodia, the Solomon Islands, Sudan, Vanuatu). ${ }^{70}$

Assessing and improving the investment climate in developing countries, including the LDCs, is another important activity of the World Bank Group. This includes the Doing Business Project. ${ }^{71}$ The World Bank's Investment Climate Assessments complement this work by identifying key constraints to investment and growth in a country, as well as areas for reform, on the basis of perceptions of entrepreneurs and firm performance in the country and their links to quantitative data collected through enterprise surveys. In addition, the World Bank Group's Facility for Investment Climate Advisory Services funds and supports advisory projects to improve the investment climate. ${ }^{72}$ Moreover, the World Bank Group's Global Investment Benchmarking exercise gives policy makers a measure of the

\footnotetext{
${ }^{66}$ MIGA's performance standards address assessment and management of environmental and social risks and impacts; labour and working conditions; resource efficiency and pollution prevention; land acquisition and involuntary settlement; biodiversity conservation and sustainable management of living natural resources; indigenous people; and cultural heritage. See, MIGA, "Performance standards", available at www.miga.org/projects/index.cfm?stid=1828 (last visited 25 June 2013).

${ }^{67}$ MIGA, Investment Guarantees: Small Investment Programme, available at www.miga.org/investmentguarantees/index.cfm?stid=1801 (last visited 25 June 2014). The program is also available to large TNCs, as long as their projects in the eligible countries meet certain criteria.

68 See, World Bank, "Fragile and conflict affected situations (FY14)," available at http://web.worldbank.org/WBSITE/EXTERNAL/PROJECTS/STRATEGIES/EXTLICUS/0,,CONTENTMDK:22978911 menuPK; 4168000 MENU 911PK;4168000 pagePK:4168000 pagePK64171540 piK:64171528!piPK:64171528 theSitePK:51178,00.ht $\mathrm{ml}$ (last visited 25 June 2014). This list is adjusted from year to year, with a new list becoming available on 1 July 2014.

${ }^{69}$ See, http://www.miga.org/news/index.cfm?aid=3522 (last visited 25 June 2014).

70 “Affordable dispute resolution", available at https://www.wbginvestmentclimate.org/advisory-services/regulatorysimplification (last visited 25 June 2014).

${ }^{71}$ World Bank, "Investment climate: Data and indicators", available at: http: www.wbginvestmentclimate.org/research-anddiagnostics/ (last visited 25 June 2014).

722013 Annual Review: FIAS - The Facility for Investment Climate Advisory Services (Washington DC: The World Bank Group, 2013), available at www.wbginvestmentclimate.org/publications/upload/FIAS-2013-Annual-Review.pdf (last visited 25 June 2014).
} 
effectiveness with which a country's investment promotion intermediaries/agencies respond to potential investors and meet the latter's information needs. ${ }^{73}$

Finally, the World Bank has set up a number of trust funds to support countries with large extractive resources negotiate deals with foreign investors, such as the Extractive Industry Transparency Initiative (EITI) and the Extractive Industry Technical Advisory Facility (EITAF). ${ }^{74}$ The EITI multi-donor trust fund provides resources to countries to implement EITI standards of transparency, and the EITAF trust fund helps build capacity for governments to negotiate on their own behalf. (As of May 2014, EITI compliant LDCs were Burkina Faso, Cameroon, Cote d'Ivoire, Liberia, Mali, Mozambique, Niger, Sierra Leone, United Republic of Tanzania, Timor Leste, Yemen, and Zambia. ${ }^{75}$ ) Moreover, the World Bank launched a new fund in 2012, to help African countries negotiate best possible deals to develop their oil, gas and mineral resources, ${ }^{76}$ this initiative is likely to benefit several LDCs in Africa endowed with such resources. The World Bank has constraints to finance actual negotiations directly through its trust funds. However, countries may be able to obtain, in the framework of country programmes (which typically take 9-12 months to negotiate), recipient-executed loans or credits from the World Bank to hire their own negotiations support. African countries, in addition, can also apply for assistance from the Africa Legal Support Facility ${ }^{77}$ (housed in the African Development Bank); this Facility has sovereign immunity and can negotiate on behalf of client countries. ${ }^{78}$

\footnotetext{
${ }^{73}$ See, The World Bank Group, in partnership with ProInvest, Global Investment Promotion Benchmarking 2012: Eyes on Africa, The Caribbean and the Pacific, available at https://www.wbginvestmentclimate.org/uploads/15709_Web.pdf (last visited 25 June 2014).

${ }^{74}$ In the context of contract negotiations, one important element to note is the increasing use of competitive tenders for granting concessions in extractive industries. If properly contracted, they could substantially increase the benefits for resource-rich countries while improving the overall investment climate.

${ }^{75}$ EITI, Progress Report 2014: Making Transparency Matter, p. 11, available at http://eiti.org/files/etr/EITI-Progress-Report2014-web.pdf (last visited 25 June 2014).

76 "World bank launches new fund to help African countries negotiate best possible deals for their oil, gas and minerals", available at http://www.worldbank.org/en/news/press-release/2012/10/05/world-bank-launches-fund-african-countries-negotiatedeals-for-oil-gas-minerals (last visited 25 June 2014).

${ }^{77}$ See, "African Legal Support facility: Summary of key features," available at http://siteresources.worldbank.org/INTDEBTDEPT/Resources/468980-1208804666078/4918561-1270486471332/AFDBJuly2010.pdf (last visited 25 June 2014). The ALSF was established in 2010 in response to a call by African Ministers of Finance to assist in three key areas: commercial creditor litigation, the negotiation of complex commercial transactions, and capacity building. Hosted by the African Development Bank, the ALSF provides assistance to African countries to strengthen their legal expertise and negotiating capacity in debt management and litigation, natural resources and extractive industries management and contracting, investment agreements, and related commercial and business transactions.

${ }^{78}$ For a review of other sources of negotiations support, see Columbia Center on Sustainable Investment and Humboldt-Viadrina School of Governance, "Matrix of major negotiation support institutions", available at http://ccsi.columbia.edu/files/2014/04/CCSI-Compilation-of-NSIs-May-2014.pdf (last visited 25 June 2014). For example, the International Senior Lawyers Project is an international NGO that delivers pro bono legal services to nongovernmental organizations and certain LDC governments in support of projects that advance human rights, the rule of law and equitable and sustainable economic development. The Project's natural resources and related sectors programme started in Liberia in 2006, and in 2014 included Guinea, Liberia, Madagascar, Malawi, Mozambique, Rwanda, Senegal, Sierra Leone, Tanzania, and Zambia. Much of it involves law reform and capacity building through in-depth practical training workshops in such subjects as negotiating and drafting large-scale investment contracts, managing and monitoring contract compliance, legislative reform and public procurement. In Liberia, Malawi and Sierra Leone, the Project's work also involved substantial assistance from both retired and practicing lawyers from global law firms in negotiating some of the most important contracts these countries have ever entered into. See, "ISLP: International Senior Lawyers Project", available at http://www.islp.org (last visited 25 June 2014), and courtesy of ISLP.
} 
The $I L O$ is responsible for the promotion and follow-up of the Tripartite Declaration of Principles Concerning Multinational Enterprises and Social Policy. ${ }^{79}$ As part of its new follow-up mechanism, the ILO provides technical assistance to its member states, especially LDCs, on better harnessing the potential of FDI and the presence and operations of MNEs for socio-economic development and sustainable enterprise development. As part of that process, the ILO gathers information, conducts research, builds capacity, and facilitates dialogues among different actors on national development and decent work priorities. The overall objective is to align private policies and practices closer with national development priorities. This work also involves assisting companies that refer to the principles of international labour standards in their corporate policies and operations; promoting the effective use of the ILO Declarations in the world of work in co-operation with employers and workers' organisations; and providing guidance to governments that seek to attract more investment and to increase trade without compromising workers' rights and decent employment creation.

In the context of this work, the ILO has been involved in a factory-monitoring project, "Better Factories, Cambodia", since 2001, involving the ILO, the Government of Cambodia, garment manufacturers, and trade unions. The project was originally linked to the United States-Cambodia Textile and Apparel Trade agreement signed in 1999 that imposed minimum labour-use standards on exporting firms. That project continues with ILO assistance, although the trade agreement is no longer in effect. ${ }^{80}$ Similar "Better Works" projects involving the ILO are now operating in six other countries, including the LDCs Haiti and Lesotho, and are planned to be expanded further, including through a project in Bangladesh announced in October 2013. Similar activities are taking place in other sectors. Notably, the ILO is stepping up its efforts to promote decent work in the extractive industries. Through technical assistance, the ILO is working to strengthen sectoral dialogue with the objective of enhancing the positive contribution of the extractive industries to broader job creation, skills development, economic diversification, and local economic development. This work is taking place in such LDCs as Angola, Mozambique and Zambia, in line with national development priorities and in close collaboration with governments, as well as national employers and workers' organizations.

\section{Towards an action plan for FDI in LDCs}

Host and home countries as well as international agencies involved in efforts to mobilize FDI for the sustainable development of the LDCs have come a long way in achieving their objectives with respect to setting up policies and programmes for that purpose. But more could be done. Many LDCs still receive limited FDI flows in a narrow range of industries. Given the consensus among the LDCs that FDI can play an important complementary and catalytic role in their development, it is important for them, as well as their development partners - home countries, international and national development agencies, TNCs, domestic firms, civil society -- to strengthen their ongoing efforts as well as to pursue new and innovative initiatives to increase FDI flows to the LDCs and enhance host-country benefits of these flows. This could

\footnotetext{
${ }^{79}$ ILO, Tripartite Declaration of Principles Concerning Multinationals and Social Policy (Third edition) (Geneva: International Labour Office, 2001), available at http://www.ilo.org/empent/Publications/WCMS_101234/lang--en/index.htm (last visited 25 June 2014).

${ }^{80}$ Dennis Arnold, "Better work or 'ethical fix'? Lessons from Cambodia's apparel industry”, Global Labour Column, edited by Corporate Strategy and Industrial Development, available at http://column.global-labour-university.org/2013/11/better-work-orethical-fix-lessons-from.html (last visited 25 June 2014).
} 
usefully be done in the framework of an Action Plan for FDI in LDCs, an aid-for-investment programme that could contain the following elements:

\subsection{Actions by LDCs}

Much of the challenge lies with the LDCs themselves. They need to take further steps towards better rules and regulations governing FDI entry, operations and treatment (including treatment with respect to exit from a host country, which can assume considerable importance for TNCs as host LDCs develop and undergo structural changes) so as to encourage larger beneficial FDI inflows to a wider group of industries, especially those that are of particular importance for their development process. They should also integrate investment policy with trade, industrial development and other economic policies in order to meet larger development goals. Furthermore, they need to strengthen their investment promotion efforts with respect to FDI in general, as well as with respect to sectors of particular importance to them. They should focus such efforts more strongly on attracting FDI from developing countries, given the importance and rising share of FDI from those countries in world FDI as well as FDI in LDCs. Moreover, their expatriate communities abroad constitute a potential reservoir of FDI. ${ }^{81}$ Finally, they should take further steps towards improving the rules, regulations and procedures involved in establishing and operating affiliates of foreign companies, as well as for business in general, drawing upon experiences of other countries and resources available from home countries, development agencies and international organizations. The earlier review (section 2a) of what countries do to attract more FDI and benefit from it can be used for guidance in this regard. At the same time, LDCs, like other countries, would benefit from cost-benefit analyses of various measures (e.g., no intervention versus intervention, investment promotion versus linkage promotion, general policies versus specific FDI policies), and from analytical work assessing the effectiveness of different types of measures to promote FDI.

There are also a number of actions that LDCs could take that have not yet been considered by many of them, and there are actions that could be taken that are largely novel, all aimed at attracting more FDI beneficial to host LDCs and increasing the benefits of this investment to their economies.

\subsubsection{Attracting more FDI of benefit to host LDCs}

Thus, while further steps along the lines mentioned above could encourage larger and more diversified flows of FDI, in some industries, especially infrastructure (including electric power, telecommunications, transport, water) where the costs are high and the returns uncertain and long-term, and where, moreover, host countries have an interest in retaining some control, LDCs need to consider further implementation of public-private partnerships (PPPs) open to FDI. Host-country financing for such projects could draw upon official development assistance (ODA), with ODA financing a part of the project. The shortage of infrastructure services is a serious obstacle to accelerating growth and development in the LDCs. Inadequate power supply, in particular, is a major impediment to industrial expansion, economic

\footnotetext{
${ }^{81}$ See, e.g., Amadou Boly, Nicola Daniele Coniglio, Francesco Prota, and Adnan Seric, "Diaspora investments and firm export performance in selected sub-Saharan African countries," World Development, vol. 59 (2014), pp. $422-433$.
} 
development and improved welfare in many of the LDCs. More beneficial investment in industry through FDI in traditional modes as well as PPPs can be an important part of the solution.

As part of their efforts to attract FDI, LDCs might consider appointing a foreign direct investment ombudsperson in their respective economies, to address foreign investors' grievances and help prevent investor-state disputes. ${ }^{82}$ As a person respected by the government and the business community, the ombudsperson can serve as an after-care institution in the host economy and can help resolve grievances of foreign affiliates vis-à-vis governments and of governments vis-à-vis foreign affiliates, thereby preventing them from escalating into investor-state disputes. Equally important, by pre-emptively addressing foreign investors' grievances through an ombudsperson, LDCs can induce the re-investment of earnings from FDI, which comprise a quarter or more of FDI in their economies.

\subsubsection{Increasing host-country benefits from FDI}

At the same time, host LDCs should strengthen their efforts to increase the benefits from FDI to their economies and to particular groups affected by FDI and the operations of TNCs. One area for action involves the launching and/or strengthening of linkage programmes, through which local firms become suppliers to foreign affiliates located in host countries. Such linkages are one of the most important mechanisms for domestic firms to acquire the tangible and intangible assets that foreign affiliates typically possess. ${ }^{83}$ Since foreign affiliates, especially when part of global value chains, need to produce at the frontier of international competitiveness, they may often be prepared, out of their own self-interest, to help local firms upgrade themselves. However, as the experience of a number of countries, ranging from Hungary to Singapore, has shown, host country governments need to help their own firms to become linkage-ready. ${ }^{84}$

Another area for action and cooperation relates to the standards and practices host countries require of TNCs operating in their economies. Some LDCs already require adherence to certain specific standards of corporate social responsibility on the part of TNCs operating in their economies.

Finally, most LDCs are members of the ILO, so that the ILO Declaration of Fundamental Principles and Rights at Work applies, in principle, to them, including as regards employees in foreign affiliates. LDCs

\footnotetext{
${ }^{82}$ The Republic of Korea is one of the countries with a foreign investment ombudsperson, and this approach has been credited with resolving investors' grievances and inducing reinvestment or increased investment (see, "Remarks by Dr. Choong Yong Ahn, Foreign Investment Ombudsman, Republic of Korea, at the 2012 International Agreements (IIA) Conference of the World Investment Forum," available at

http://www.investkorea.org/ikwork/ombsman/eng/au/index.jsp?num=8\&no=609280001\&bno=205210048\&page1=1\&sort_num= 546 (last visited 25 June 2014).

${ }^{83}$ In this context, a recent review of literature on linkages between extractive TNCs (generally held to have limited scope for linkages with domestic firms in developing countries) and local industry in Africa concludes on a positive (though cautious) note as regards opportunities presented by extractive FDI in terms of the formation and deepening of linkages. See Michael Hansen, "From enclave to linkage economies? A review of the literature on linkages between extractive multinational corporations and local industry in Africa", DIIS Working Paper 2014:02, Danish Institute for International Studies, available at http://en.diis.dk/files/publications/WP2014/wp2014-02\%20Michae1\%20Hansen\%20for\%20web.pdf (last visited 25 June, 2014). See also, Vito Amendolagine, Amadou Boly, Nicola Daniele Coniglio, Francesco Prota, and Adnan Seric, "FDI and local linkages in developing countries: Evidence from sub-Saharan Africa," World Development, vol. 50 (October 2013), pp. 41-56.

${ }^{84}$ For a comprehensive discussion of linkages between foreign affiliates and domestic firms in host countries and policies for linkage promotion, see UNCTAD, World Investment Report 2001: Promoting Linkages (Geneva: United Nations), Part Two.
} 
could also consider adhering to the OECD Guidelines for Multinational Enterprises, ${ }^{85}$ so as to minimize possible negative outcomes of FDI in a range of areas as specified by the Guidelines.

\subsection{Actions by home countries and other development partners}

As discussed earlier, individual home countries (and especially developed ones) have various home country measures in place, meant to help their firms invest abroad. For virtually all of these measures, home countries should consider making them more attractive to firms that are prepared to invest in LDCs. ${ }^{86}$ Moreover, consideration should be given to link the provision of home country measures to the adherence by the beneficiaries to a core set of economic development, social and labour standards. The MIGA criteria ${ }^{87}$ for investment guarantees (mentioned earlier) could be a partial model here. More specifically, the observance of these environmental and social sustainability criteria could be linked to the granting of financial and fiscal home-country assistance, as well as political risk insurance (reviewed in section 2). Adding to these criteria the requirement of making every reasonable effort to contribute as much as possible to the development of LDCs would be emulating the best practices of some home countries. The resulting projects would thus acquire the characteristics of "sustainable FDI projects", i.e., projects that contribute as much as possible to the economic, social and environmental development of host countries and take place in the context of fair governance mechanisms. ${ }^{88}$ The inclusion, in international investment agreements, of language that provides for countries to encourage firms to observe corporate social responsibility standards can help and is desirable. ${ }^{89}$

Another action that could be considered by individual home countries is to provide home-country equity and other assistance to SMEs investing in LDCs by arrangements similar to those in the Netherlands for SMEs investing in Palestine, under which the Dutch Development Organization provides a part of the investment and provides for political-risk insurance. ${ }^{90}$

\footnotetext{
${ }^{85}$ OECD, OECD Guidelines for Multinational Enterprises: 2011 Edition (Paris: OECD, 2011), available at http://www.oecd.org/investment/mne/48004323.pdf (last visited 25 June 2014).

${ }^{86}$ For example, Joseph Stiglitz has proposed that the United States, a major home country, should not only renew AGOA well beyond 2015, to provide predictability for manufacturers, buyers and investors, but should also work to make it more effective for instance, by relaxing rules of origin and offering tax incentives to United States companies investing in non-oil sectors. Renewing AGOA legislation in this way would offer an opportunity to facilitate the integration of African SMEs into global value chains. (Joseph Stiglitz, "A new American strategy for business in Africa”, Financial Times, 4 August 2014.

${ }^{87}$ MIGA, "Environmental and social sustainability", available at http://www.miga.org/projects/index.cfm?stid=1822 (last visited 25 June 2014).

${ }^{88}$ For a discussion of the concept of "sustainable foreign direct investment" (or "sustainable international investment"), see, Karl P. Sauvant and Federico Ortino, Improving the International Investment Law and Policy Regime: Options for the Future (Helsinki: Ministry for Foreign Affairs, 2013), pp. 99-101.
}

${ }^{89}$ For example, the Canada-Republic of Korea Free Trade Agreement contains the following language:

"Article 8.16: Corporate Social Responsibility

Each Party should encourage enterprises operating within its territory or subject to its jurisdiction to voluntarily incorporate internationally recognised standards of corporate social responsibility in their practices and their internal policies, including statements of principle that are endorsed or supported by the Parties. These principles address issues such as labour, environment, human rights, community relations, and anti-corruption." See, http:/www.international.gc.ca/trade-agreements-accordscommerciaux/agr-acc/korea-coree/08.aspx.

${ }^{90}$ For an example of a project supported by the Dutch programme, see, http://www.miga.org/projects/index.cfm?pid=1292 (last visited 25 June 2014). 
In addition, home countries and other development partners should consider pursuing further initiatives specifically to promote FDI in the LDCs and enhancing its benefits for host economies. These include:

- Providing rapid-response negotiations support to assist LDCs in negotiating complex large-scale contracts with foreign investors. Many large FDI projects, especially those relating to the exploitation of natural resources, infrastructure, privatizations, and PPPs, involve contracts between investors and host-country governments. Most LDC governments do not have the world-class resources required to negotiate fair deals in these areas, and thus may lose the opportunity to maximize the benefits of major FDI projects for their countries, or restrict foreign participation due to fear of negative outcomes due to limited negotiating capabilities. This is all the more important as such contracts typically concern major sources of income for LDCs, for years to come, and hence can contribute significantly to a self-financed graduation from LDC status. At the same time, unfair contracts are sooner or later likely to lead to a request for renegotiations on the part of host countries, with the risk of disruptions of production and the potential for conflicts. Both, host countries and TNCs, have therefore an interest in fair and stable contracts. Support for the LDCs in contract negotiations (perhaps supported by a revolving fund, based on an initial endowment) could help level the playing field between the LDCs and TNCs with abundant access to negotiating expertise, thereby leading to more durable contracts. Negotiations support requested by LDCs could encompass an information platform relating to the negotiation of contracts; ${ }^{91}$ a referral service for LDC negotiators wanting to obtain information about where they might be able to obtain specific information or assistance; and the capacity rapidly (i.e., within weeks) to field multi-disciplinary teams that can help LDCs anywhere in the world in actual negotiations of complex, large-scale contract negotiations, regardless of the industries involved. ${ }^{92}$ Such support should of course leverage existing initiatives to the extent possible; but, beyond that, it should also fill gaps, especially by providing actual negotiations assistance.

It is encouraging in this respect that the Group of 7, in its June 2014 Summit, has announced "a new initiative on Strengthening Assistance for Complex Contract Negotiations (CONNEX) to provide developing country partners with extended and concrete expertise for negotiating complex commercial contracts, focusing initially on the extractives sector, and working with existing fora and facilities to avoid duplication, to be launched in New York in June and to deliver improvements by our next meeting, including as a first step a central resource hub that brings together information and guidance." 93 Furthermore, "the G-7 leaders also committed to establish a G-7-led steering committee to lead the further process of improving expert assistance for negotiation support, including identifying any gaps in existing assistance as a first step toward developing rapid response teams to provide contract negotiation assistance to developing countries as soon as it is needed. The platform will launch on June 17 in New York in association

\footnotetext{
${ }^{91}$ See the Knowledge Portal being developed by the Columbia Center on Sustainable Investment and launched 17 June 2014 ; see, www.negotiationsupport.org

${ }^{92}$ For a concept paper, see Humboldt-Viadrina School of Governance, "Establishing a negotiations support facility," available at http://www.humboldt-viadrina.org/eng/research/current-research-areas/negotiation-support-initiative/ (last visited 25 June 2014).

${ }^{93}$ See, "The Brussels G7 Summit Declaration," European Commission - MEMO/14/402 05/06/2014, available at http://europa.eu/rapid/press-release_MEMO-14-402_en.htm (last visited 25 June 2014).
} 
with the Columbia Center on Sustainable Investment at Columbia University." 94 It would be highly desirable if this improvement of expert assistance could be done as soon as possible, and if priority could be given to negotiating assistance to LDCs.

- At the same time, LDCs could commit themselves to a stronger enforcement of contracts signed between them and foreign investors, e.g., by becoming signatories to the Convention on the Recognition and Enforcement of Foreign Arbitral Awards (New York Convention). The Convention obliges contracting states (including the 22 LDCs that are signatories) to recognize and enforce arbitral awards. ${ }^{95}$

- While negotiations support would help prevent that conflicts arise between investors and LDCs, it is almost certain that, under certain circumstances, such conflicts will arise nevertheless. In fact, as the LDCs become hosts to growing FDI in a range of activities and, simultaneously, parties to more international investment agreements, the prospects for treaty-based investment disputes are likely to rise. As of June 2014, LDCs were respondents in 36 such investment disputes. ${ }^{96}$ Hence, it would be desirable for home countries to consider the creation of an advisory centre for treatybased investment disputes, to assist LDCs in the handling of such disputes. Such an advisory centre could be patterned on the WTO Advisory Centre on WTO Law, ${ }^{97}$ which provides free legal advice to developing countries on WTO law and support in WTO dispute settlement proceedings at discounted rates. Such a centre would not only save costs for LDCs that are respondents in such disputes and help them to defend themselves against unjustified claims and the potentially high damages involved, but - by giving LDCs a fair chance to benefit from the investor-state dispute settlement mechanism typically included in international investment agreements -- it would also strengthen the legitimacy of the international investment law and policy regime (which is under criticism from various quarters). ${ }^{98}$

- Support for Tax Inspectors without Borders. FDI and international production bring with them a range of issues relating to taxation that home as well as host countries need to address, and this applies even more to the LDCs. Abusive transfer pricing and international tax planning by TNCs can lead to the erosion of the tax base and the shifting of profits that result in a loss of revenue for a host country as well as a distortion of investment decisions and unintended competitive advantages for TNCs over domestic businesses. ${ }^{99}$ In this context, home countries and other development partners should support the "Tax Inspectors Without Borders" initiative started by the OECD with an initial 18-month mandate (till December 2014) and to be fully launched later

\footnotetext{
94 The White House, "FACT SHEET: The 2014 G-7 Summit in Brussels", available at http://www.whitehouse.gov/the-pressoffice/2014/06/05/fact-sheet-2014-g-7-summit-brussels (last visited 25 June 2014). The Negotiation Support Portal was indeed launched on that date and is available at: http://www.negotiationsupport.org.

${ }^{95}$ UNCITRAL, "Convention on the Recognition and Enforcement of Foreign Arbitral Awards (New York, 1958)", available at http://www.uncitral.org/pdf/english/texts/arbitration/NY-conv/XXII_1_e.pdf (last visited 25 June 2014).

${ }^{96}$ Data courtesy of UNCTAD. The most frequent LDC respondents were Democratic Republic of Congo (8 claims); Burundi (5); Tanzania and Yemen (4 each); and Bangladesh (3).

${ }^{97}$ Information on the WTO Advisory Centre is available at http://www.acwl.ch/e/index.html (last visited 25 June 2014).

${ }^{98}$ Such a mechanism could also reduce the likelihood that FDI in some sectors is restricted due to the anticipation of disputes.

99 OECD, Action Plan on Base Erosion and Profit Shifting (Paris: OECD, 2013), pp. 36-37, available at http://www.oecdilibrary.org/taxation/action-plan-on-base-erosion-and-profit-shifting_9789264202719-en (last visited 25 June 2014).
} 
in $2015^{100}$ - and mandate that Organisation to give priority to the LDCs in this respect. The initiative aims at enabling the transfer of tax audit knowledge and skills to administrations in developing countries through a "learning by doing" approach in which experts are deployed to work directly with local tax officials (in tax administrations seeking assistance) on current audits and audit-related issues concerning international tax matters, and to share knowledge of general audit practices. In addition to the transfer of knowledge and know-how, broader benefits from the initiative include the potential for more revenues, greater certainty for tax-payers and the encouragement of a culture of tax compliance through more effective enforcement.

\subsection{Actions by TNCs, local industry and NGOs}

The impact of FDI on sustainable development in host LDCs depends not only on the activities in which investment is made and the ability of domestic firms and human resources to establish linkages with foreign affiliates (which local firms should embrace), but also on the extent to which the foreign affiliates act as good corporate citizens with an interest in promoting sustainable development in their host countries. As noted, some home countries make help to outward investors dependent on meeting certain impact criteria; similarly, TNCs receiving financial support from the IFC need to meet IFC impact criteria for project finance. TNCs should fully embrace these criteria and also consider observing them when not benefitting from home country measures or IFC support.

Furthermore, TNCs should fully observe (including for their value chains) the OECD Guidelines, and publicly commit themselves in this respect. They should also do the same for the United Nations Guiding Principles on Business and Human Rights, endorsed by the United Nations in June $2011,{ }^{101}$ and the various other international instruments that seek to encourage good corporate behavior. (As mentioned earlier, such observance can also be furthered by including encouraging language in international investment agreements.) The fact that 8,000 companies had joined the United Nations' Global Compact as of $2013,{ }^{102}$ committing to adopting a principles-based management and operations approach, suggests that there is considerable scope for the sharing of non-proprietary knowledge and expertise by foreign affiliates and their parent companies with domestic firms in the LDCs. At the individual company level, many individual TNCs have their own corporate social responsibility policies, and these can be very useful. It would be desirable if these policies were put on a firmer ground by dedicating a certain percentage of the earnings of parent firms to foreign affiliates in LDCs undertaking clearly defined

100 See, http://www.oecd.org/ctp/tax-global/tax-inspectors-without-borders-summary.pdf (last visited 25 June 2014); and http://www.oecd.org/ctp/oecd-secretary-general-tax-report-g20-finance-ministers-february-2015.pdf (last visited 25 March 2015).

101 The "Guiding Principles" were based on six years of work by the former Special Representative of the United Nations Secretary-General, Professor John Ruggie. Their endorsement by the United Nations Human Rights Council established them as the global standard of practice that is now expected to be observed by all states and businesses with regard to business and human rights (United Nations Human Rights, Office of the High Commissioner, Guiding Principles on Business and Human Rights: Implementing the United Nations "Protect, Respect and Remedy" Framework (Geneva: United Nations, 2011), available at http://www.ohchr.org/Documents/Publications/GuidingPrinciplesBusinessHR_EN.pdf (last visited 25 June 2014); see also, United Nations Human Rights Office of the High Commissioner, The Corporate Responsibility to Respect Human Rights: An Interpretive Guide (Geneva: United Nations, 2012), available at http://www.ohchr.org/Documents/Issues/Business/RtRInterpretativeGuide.pdf (last visited 23 June 2014).

${ }^{102}$ United Nations Global Compact, Global Corporate Sustainability Report 2013 (New York: United Nations Global compact Office, 2013), p. 4, available at http://www.unglobalcompact.org/docs/about_the_gc/Global_Corporate_Sustainability_Report2013.pdf (last visited 25 June 2014). 
corporate social responsibility activities in their (LDC) host countries, ${ }^{103}$ creating in this manner the financial and corporate governance basis for sustainable FDI. TNCs, local firms, business associations, and NGOs in LDCs need to co-operate in promoting further sharing of ideas, knowledge and expertise through information exchange, meetings and conferences involving executives and experts from TNCs, as well as training programmes for local human resources and other direct actions. There were some 2,000 civil society signatories to the United Nations Global Compact as of 2013, indicating the interest of NGOs and other members of civil society in holding companies, including TNCs, accountable for their investments and in partnering with businesses on common causes. ${ }^{104}$

\subsection{Action by international organizations}

As noted, several international organizations, including especially UNCTAD, UNIDO, the World Bank Group, and the ILO, but also other United Nations agencies and international organizations provide technical assistance to developing countries to help the latter attract and benefit from FDI. Given the urgency of accelerating the development process of the LDCs and help them graduate from their group, there is a case for extending some of the initiatives already under way in developing countries in general to the LDCs, or, where these are already eligible, giving priority to them. Consideration should be given, among others, to:

- Giving priority to the LDCs in implementing the G-7's new initiative to assist developing countries in negotiating large-scale complex contracts with foreign investors. Resource-rich LDCs in all parts of the world are in particular need of such assistance, but so are LDCs in general that negotiate the terms and conditions for the utilization of their scarce assets in order to get the best possible deal.

- Strengthening mechanisms to ensure that TNCs and their foreign affiliates operating in the mineral industries adhere to the OECD Due Diligence Guidance for Responsible Supply Chains of Minerals from Conflict-Affected and High-Risk Areas. ${ }^{105}$ It provides guidance to companies operating in, or sourcing, materials from conflict-affected and high-risk areas (many of which are LDCs), consistent with applicable laws and international standards. The supplements to the Guidance contain specific due diligence recommendations articulated on the basis of companies' different positions and roles in their supply chains.

\footnotetext{
${ }^{103}$ This would be a variation of what India's Companies Act 2013 mandates. In section 135, the Indian law, which became effective at the beginning of the financial year 2014-2015, requires that the Board of every company having a net worth, turnover or profit above a designated amount shall take a number of steps to adopt a corporate responsibility policy and ensure that the company spends, in every financial year, at least two per cent of the average net profits of the company made during the three immediately preceding financial years, in pursuit of its corporate responsibility policy (The Gazette of India Extraordinary, Ministry of Law and Justice, 30 August 2013, The Companies Act 2013, available at http://indiacode.nic.in/acts-inpdf/182013.pdf (last visited 27 May 2014). The end of the first reporting year under the law for Indian companies will be March 31, 2015, and companies are still at an inception stage in designing their CSR activities. The Government of India has indicated that the CSR activities should be undertaken only in a "project/programme" mode and that one-off events such as awards, charitable contributions etc. would not be qualified as CSR expenditures ("Government provides clarity on CSR activities under Companies Act", Times of India, June 19, 2014, available at: http://timesofIndia.indiatimes.com/business/India-business/Govtprovides-clarity-on-CSR-activities-underCompanies-Act/articleshow/36833349.cms (last visited 8 September, 2014)).

${ }^{104}$ United Nations Global Compact, Global Corporate Sustainability Report 2013, op. cit.

105 OECD, Due Diligence Guidance for Responsible Supply Chains of Minerals from Conflict-Affected and High Risk Areas (Paris: OECD, 2013), available at http://www.oecd.org/investment/mne/GuidanceEdition2.pdf (last visited 24 June 2014).
} 
- Extending risk insurance provided by MIGA (as well as national political risk insurers) to global value chain affiliates outside an affected host country. For example, if political instability in country A leads to a temporary suspension (or severe restriction) of production in a value-chain foreign affiliate in that country, this would immediately affect the ability of an affiliate in the same value chain in country B that depends on inputs from its value-chain affiliate in country A. Currently, only the affiliate in country A would be potentially eligible to benefit from its insurance with MIGA, even though the affiliate belonging to the same supply chain in country B has been (perhaps equally) affected. Given that political risk is seen to be high in LDCs, providing such supply-chain insurance would help these countries to link up with global value chains ${ }^{106}$ arrangements which are increasingly driving not only global investment but also trade. ${ }^{107}$

- Drawing the attention of investors in emerging markets to MIGA's political risk insurance services. While MIGA's services are well known to investors in developed countries, this is less so in other countries. Such awareness is particularly important because firms headquartered in emerging markets ${ }^{108}$ accounted for US\$ 550 billion of outward FDI flows in 2013, more than ten times what world FDI flows were during the first half of the 1980s. ${ }^{109}$ Yet, many investors in emerging markets are not aware of MIGA's political risk services, which could limit their inclination to invest in LDCs.

- As discussed earlier, disputes that arise between investors and host country governments can become treaty-based international investment disputes subject to potentially costly arbitration. Hence, seeking to prevent such disputes from arising is an important matter. Reference has already been made to the possibility of LDCs appointing investment ombudspersons, as one (informal) mechanism to accomplish this. Another, formal, approach is being pioneered by the IFC in southern Europe and Mongolia, and is about to start in Latin America -- namely to work with host countries to establish an investor-grievance management mechanism, to help governments better manage investor grievances relating to at least the following investorprotection guarantees: protection from expropriation, freedom to transfer and convert currencies, protection from adverse regulatory changes, and breach of contract. A designated lead agency within the government manages and implements this mechanism. Essentially, it provides the minimum institutional infrastructure that enables governments to identify, track and manage grievances arising between investors and public agencies as early as possible. The mechanism seeks to ensure that the government responds to investor grievances in a suitable manner and in accordance with the country's international investment agreements, laws and regulations. Ultimately, this mechanism is meant to contribute towards retaining existing investment,

\footnotetext{
${ }^{106}$ Such extension to the supply chain could be considered, of course, not only by MIGA but also other national and international insurers. And perhaps consideration could also be given to extending insurance to value-chain interruptions on account of natural disasters.

${ }^{107}$ For a discussion, see UNCTAD, World Investment Report 2013, op. cit. Also see OECD, "Interconnected economies: Benefiting from global value chains. Synthesis report" (Paris: OECD, 2013), available at

http: www.oecd.org/sti/ind/interconnected-economies-GVC-Synthesis.pdf (last visited 26 June 2014); and OECD, WTO and UNCTAD, "Implications of global value chains for trade, investment, development and jobs," paper prepared for the G-20 Leaders' Summit, St. Petersburg (Russian Federation), September 2013, available at http: //www.oecd.org/trade/G20-GlobalValue-Chains.pdf (last visited 26 June 2014).

108 All firms from countries not classified as developed by UNCTAD.

${ }^{109}$ See, UNCTAD, FDI database, at http://unctadstat.unctad.org/ (last visited 25 June 2014).
} 
encouraging re-investment and preventing investor-state disputes. The IFC should consider making this facility available on a priority basis to LDCs requesting its implementation.

\section{Conclusions}

Strengthening the regimes and measures for promoting FDI in the LDCs and assisting these countries in attracting FDI and maximizing benefits from it, remains a difficult challenge. Meeting this challenge requires the determined and coordinated efforts of a large number of stakeholders.

The promising trends in FDI flows to the LDCs in recent years and the nascent shifts in their sectoral distribution towards manufacturing and service activities suggest scope for further efforts by the LDCs, home countries, the international community and others for promoting FDI flows that contribute to these countries' productive capacity building. Greater coordination of such efforts through a Common Information Base on FDI in LDCs, as a one-stop shop for information on the range of issues relating to investing in LDCs (including, e.g., laws and regulations), could contribute towards the success of such efforts. It would be a facility on which all concerned could draw in their efforts to promote FDI, including by encouraging it towards activities that enhance the technological base of LDCs $^{110}$ and strengthen productive capabilities in general.

Even more importantly, it would be worthwhile for the international community to consider launching an Action Plan for Promoting FDI in the LDCs and strengthening host-country benefits. The centrepiece of such an Action Plan could be the Common Information Base, around which some of the activities mentioned earlier in this report (as well as others) could be grouped. Within the framework of such an Action Plan, developments could be monitored, the exchange of information among various stakeholders could be facilitated and advice and assistance could be provided to strengthen LDC capabilities to attract increased FDI flows and increase the benefits from FDI for productive capacity building and sustainable growth.

\footnotetext{
${ }^{110}$ Note that, following on commitments made in the Istanbul Declaration and Istanbul Programme of Action adopted at the Fourth United Nations Conference on the Least Developed Countries in 2011, and a report of the Secretary General prepared upon the request of the General Assembly, it has been decided to establish a Technology Bank for the LDCs, comprising a patents bank; a science, technology and innovation supporting mechanism; and a science and technology research depository facility. This would be an important step towards strengthening the technological capacities of LDCs. (See, UN-OHRLLS, State of the Least Developed Countries, 2013 (New York: UN-OHRLLS, 2013), appendix 3.2). At the same time, such a facility and its impact could also make LDCs more attractive to technology-intensive FDI.
} 


\section{References}

Arnold, Dennis (2013). Better work or 'ethical fix'? Lessons from Cambodia's apparel industry, Global Labour Column, edited by Corporate Strategy and Industrial Development, available at: http://column.global-labouruniversity.org/2013/11/better-work-or-ethical-fix-lessons-from.html.

Cotula, Lorenzo, Sonja Vermeulen, Rebeca Leonard, and James Keeley (2009). Land grab or development opportunity? Agricultural investment and international land deals in Africa, IIED/FAO/IFAD, London/Rome, 2009, available at: www.ifad.org/pub/land_grab.pdf

Dunning, John H. and S. Lundan (2008) Multinational Enterprises and the Global Economy (Cheltenham: Edward Elgar, 2008), chapter 3.

European Commission, The Cotonou Agreement: 2010 Consolidated Version, chapter 7, article 75, "Investment promotion," available at http://ec.europa.eu/europeaid/where/acp/overview/cotonou-agreement/index_en.htm. (could not find from showed website)

Harding, Torfinn and Beata Smarzynska Javorcik (2010). Roll out the red carpet and they will come: investment promotion and FDI inflows, Department of Economics, University of Warwick, Coventry, UK (CAGE Online Working Paper Series), June 2010, No.18, Permanent WRAP: http://wrap.warwick.ac.uk/57330.

Hem Socheth (2012). Foreign investment in agriculture in Cambodia: a survey of recent trends, TKN Report, Trade Knowledge Network, International Institute for Sustainable Development, Geneva, Switzerland, December 2012, available at: www.iisd.org/tkn.

Honeck, Dale (2011). Expect the unexpected: LDC GATS commitments as internationally credible policy indicators? - the example of Mali," Staff Working Paper ERSD-2011-07, World Trade Organization, 19 May 2011, available at: www.wto.org/english/res_e/ersd201107_e.pdf (last visited 25 June 2014).

ILO (2001). Tripartite Declaration of Principles Concerning Multinationals and Social Policy (Third edition) (Geneva: International Labour Office, 2001), available at: www.ilo.org/empent/Publications/WCMS_101234/lang--en/index.htm (last visited 25 June 2014).

JBIC (2012). Guidelines for confirmation of environmental and social considerations, April 2012, available at: https://www.jbic.go.jp/wp-content/uploads/page/efforts/environment/confirm_en/pdf_01.pdf.

Narula, R. and John H. Dunning (2010). Multinational enterprises, development and globalization: Some clarifications and a research agenda, Oxford Development Studies, 38(3):263-287.

OECD (2013). Action Plan on Base Erosion and Profit Shifting (Paris: OECD, 2013), pp. 36-37, available at: www.oecd-ilibrary.org/taxation/action-plan-on-base-erosion-and-profit-shifting_9789264202719-en.

OECD (2013). Due Diligence Guidance for Responsible Supply Chains of Minerals from Conflict-Affected and High Risk Areas (Paris: OECD, 2013), available at: http://www.oecd.org/investment/mne/GuidanceEdition2.pdf.

OECD (2011). OECD Guidelines for Multinational Enterprises: 2011 Edition (Paris: OECD, 2011), available at: www.oecd.org/investment/mne/48004323.pdf.

OPIC (2012). Doing business with us: Small business sector, available at: http://www.opic.gov/doing-businessus/small-business-center.

OPIC (2012). 2012 Annual Report, available at: www.opic.gov/sites/default/files/files/OPIC_2012_Final.pdf (last visited 25 June 2014).

Rugman, Alan M. and Jonathan P. Doh (2008). Multinationals and Development (Yale University Press, 2008), chapter I, available at: http://Yalepress.yale.edu/yupbooks/book.asp?aspn=9780300115611.

UNCITRAL (1958). Convention on the Recognition and Enforcement of Foreign Arbitral Awards (New York, 1958), available at: www.uncitral.org/pdf/english/texts/arbitration/NY-conv/XXII_1_e.pdf.

UNCTAD, Country-specific lists of BITs, available at http://unctad.org/en/Pages/DIAE/International\%20Investment\%20Agreements\%20(IIA)/Country-specific-Listsof-BITs.aspx. 
Policy Options for Promoting FDI in the LDCs

UNCTAD (2014). Bilateral FDI Statistics 2014, China, available at: http://unctad.org/Sections/dite_fdistat/docs/webdiaeia2014d3_CHN.pdf .

UNCTAD (2014). Division on Investment and Enterprise: Results and Impact Report, 2014, Draft Advance Copy, p. 32, available at: www.unctad.org/en/PublicationsLibrary/diae2014d2_en.pdf.

UNCTAD (2013). World Investment Report 2013: Global Value Chains. Investment and Trade for Development (Geneva: United Nations, 2013), op. cit., table D, p. 73, and data for 2012-2013 from UNCTAD, World Investment Report 2014: Investing in the SDGs. An Action Plan (Geneva: United Nations, 2014), table D, p. 82, available at: www.unctad.org/en/PublicationChapters/wir2014ch2_en.pdf (last visited 26 June 2014).

UNCTAD (2014). World Investment Report 2014, op. cit., tables E and C, p. 82.

White House (2014). FACT SHEET: The 2014 G-7 Summit in Brussels, available at: www.whitehouse.gov/thepress-office/2014/06/05/fact-sheet-2014-g-7-summit-brussels. The Negotiation Support Portal was indeed launched on that date and is available at: www.negotiationsupport.org.

World Bank, available at: www.doingbusiness.org/custom-query.

World Bank, available at: www.doingbusiness.org/data/distance\%20to\%20frontier.

\section{Acknowledgements}

The authors would like to thank the United Nations Office of the High Representative for the Least Developed Countries, Landlocked Developing Countries and Small Island Developing States (UNOHRLLS), particularly, Khalilur Rahman, Chief of Policy Development and Coordination for the Least Developed Countries and his team, for their encouragement, substantive support and feedback in the preparation of this text. Thanks go also to Abdul Alim, Phillip Bastian, Youri Bless, Tomas Gonzalez, and Louise Stoddard for their assistance; to a number of colleagues in international organisations for their feedback; and to Nikia R. Clarke, Michael W. Hansen, Terutomo Ozawa, Peter Nunnenkamp, and Louis T. Wells for reviewing the paper and providing thoughtful comments. This paper appeared earlier, under the title "Strengthening Investment Promotion Regimes for Foreign Direct Investment in the Least Developed Countries", in the Occasional Policy Papers Series on the Least Developed Countries, issued by UNOHRLLS. The series, edited by Khalilur Rahman, is prepared under the general guidance of the Under Secretary-General and High Representative and the overall supervision of the Director of the UNOHRLLS. All links referenced in this paper were last accessed on 25 June 2014, unless otherwise indicated. Any errors contained in this paper are of course those of the authors.

\section{About the Authors}

Karl P. Sauvant (karlsauvant@gmail.com) is Resident Senior Fellow, Columbia Center on Sustainable Investment (CCSI), a joint center of Columbia Law School and The Earth Institute at Columbia University, New York; he was the Founding Executive Director of the predecessor of CCSI, the Vale Columbia Center on Sustainable International Investment, and the Director of UNCTAD's Investment Division. Padma Mallampally is an economist and former staff member of UNCTAD's Investment Division.

\section{Contact Information}

The authors can be reached at Dr. Karl P. Sauvant at karlsauvant@gmail.com. 
Karl P. Sauvant and Padma Mallampally

Annex table. The least developed countries: Selected data on inward and outward FDI

\begin{tabular}{|c|c|c|c|c|c|c|c|c|c|c|}
\hline & \multicolumn{2}{|c|}{$\begin{array}{l}\text { Average annual FDI inflows } \\
\text { (US dollars, millions) }\end{array}$} & \multicolumn{2}{|c|}{$\begin{array}{l}\text { Average annual FDI outflows } \\
\text { (US dollars, millions) }\end{array}$} & \multicolumn{2}{|c|}{$\begin{array}{l}\text { FDI inflows as percentage of } \\
\text { gross fixed capital formation }\end{array}$} & \multicolumn{2}{|c|}{$\begin{array}{c}\text { Inward FDI stock (US dollars, } \\
\text { millions) }\end{array}$} & \multicolumn{2}{|c|}{$\begin{array}{c}\text { Inward FDI stock as percentage } \\
\text { of GDP }\end{array}$} \\
\hline & $2001-2003$ & $2011-2013$ & $2001-2003$ & $2011-2013$ & $2001-2003$ & $2011-2013$ & 2001 & 2013 & 2001 & 2013 \\
\hline The least developed countries & 8,046 & 24,854 & 169 & 4,490 & 18.2 & 12.7 & 42,485 & 211,797 & 21.9 & 25.9 \\
\hline Africa & 7,204 & 19,484 & 118 & 4,354 & 33.4 & 18.5 & 33,152 & 167,604 & 31.8 & 33.9 \\
\hline North Africa & 879 & 2,758 & 0 & 391 & 33.0 & 20.0 & 1,972 & 29,148 & 12.5 & 41.6 \\
\hline South Sudan & & $\ldots$ & & $\ldots$ & & $\ldots$ & & $\ldots$ & & $\cdots$ \\
\hline Sudan & 879 & 2,758 & 0 & 391 & 33.0 & 20.0 & 1,972 & 29,148 & 12.5 & 41.6 \\
\hline West Africa & 625 & 5,603 & 110 & 1,451 & 11.4 & 30.8 & 5,093 & 33,600 & 21.7 & 43.4 \\
\hline Benin & 34 & 254 & 1.3 & 49 & 6.2 & 16.3 & 174 & 1,354 & 7.0 & 16.3 \\
\hline Burkina Faso & 17 & 282 & 1.4 & 86 & 2.6 & 9.5 & 16 & 1,432 & 0.6 & 11.7 \\
\hline Gambia & 31 & 29 & $\ldots$ & $\ldots$ & 14.9 & 10.6 & 221 & 754 & 32.1 & 88.7 \\
\hline Guinea & 38 & 529 & 1.8 & 1.7 & 4.5 & 24.5 & 265 & 3,303 & 8.7 & 52.6 \\
\hline Guinea-Bissau & 3 & 15 & 0.4 & 0.3 & 4.0 & 17.8 & 38 & 112 & 9.7 & 13.2 \\
\hline Liberia & 128 & 851 & 95 & 808 & 319.8 & 437.2 & 3,255 & 6,267 & 623.5 & 324.2 \\
\hline Mali & 166 & 455 & 7 & 10 & 25.7 & 23.5 & 210 & 3,432 & 7.0 & 31.0 \\
\hline Mauritania & 82 & 1,042 & -0.3 & 4 & 30.7 & 94.6 & 223 & 5,499 & 17.2 & 131.3 \\
\hline Niger & 13 & 846 & -1.8 & 1.6 & 3.9 & 35.2 & 61 & 4,940 & 3.3 & 67.1 \\
\hline Senegal & 54 & 304 & 10 & 45 & 4.1 & 8.6 & 194 & 2,696 & 4.0 & 17.8 \\
\hline Sierra Leone & 10 & 693 & $\ldots$ & 0 & 7.4 & 64.1 & 294 & 2,319 & 26.9 & 48.4 \\
\hline Togo & 50 & 302 & -4 & 445 & 22.3 & 43.3 & 141 & 1,494 & 10.6 & 34.3 \\
\hline Central Africa & 1,573 & 4,915 & 15 & 309 & 55.4 & 30.8 & 3,964 & 27,539 & 33.0 & 46.0 \\
\hline Burundi & 0.007 & 4 & 0.004 & $\ldots$ & 0.01 & 0.7 & 47 & 16 & 7.2 & 0.6 \\
\hline Central African Republic & 7 & 36 & $\ldots$ & $\ldots$ & 8.9 & 11.3 & 109 & 620 & 11.7 & 40.3 \\
\hline Chad & 699 & 388 & $\ldots$ & $\ldots$ & 73.5 & 15.1 & 1,036 & 4,758 & 60.6 & 35.5 \\
\hline Democratic Republic of the Congo & 204 & 2,366 & 14 & 304 & 38.0 & 51.1 & 699 & 5,631 & 13.3 & 29.9 \\
\hline Equatorial Guinea & 651 & 1,968 & 1.4 & $\ldots$ & 61.3 & 30.8 & 2,001 & 15,317 & 118.0 & 98.3 \\
\hline Rwanda & 8 & 126 & $\ldots$ & 5 & 3.5 & 8.1 & 57 & 854 & 3.4 & 11.5 \\
\hline Sao Tome and Principe & 3 & 28 & & 0.3 & 13.9 & 41.2 & 14 & 345 & 20.0 & 111.9 \\
\hline East Africa & 1,034 & 4,476 & -0.04 & -0.6 & 15.6 & 14.7 & 5,681 & 37,221 & 17.6 & 30.6 \\
\hline Comoros & 0.8 & 16 & $\ldots$ & & 3.0 & 19.7 & 22 & 107 & 9.9 & 16.4 \\
\hline Djibouti & 7 & 158 & $\ldots$ & & 7.8 & 59.8 & 43 & 1,352 & 7.5 & 92.8 \\
\hline Eritrea & 20 & 41 & $\ldots$ & & 8.7 & 14.1 & 350 & 791 & 46.5 & 23.0 \\
\hline Ethiopia & 356 & 619 & $\ldots$ & & 17.9 & 5.0 & 1,291 & 6,064 & 16.2 & 12.6 \\
\hline Madagascar & 83 & 820 & -1.1 & $\ldots$ & 10.9 & 45.7 & 143 & 6,488 & 3.1 & 57.9 \\
\hline Somalia & -0.2 & 105 & $\ldots$ & $\ldots$ & -0.08 & 43.4 & 4 & 883 & 0.3 & 67.6 \\
\hline Uganda & 179 & 1,082 & $\ldots$ & -0.6 & 13.8 & 21.0 & 962 & 8,821 & 15.2 & 38.3 \\
\hline United Republic of Tanzania & 388 & 1,634 & 1.1 & & 20.3 & 16.6 & 2,867 & 12,715 & 27.0 & 39.1 \\
\hline Southern Africa & 3,093 & 1,732 & -7 & 2,203 & 77.8 & 6.4 & 16,442 & 40,097 & 78.9 & 24.2 \\
\hline Angola & 2,441 & $-4,736$ & -10 & 2,307 & 163.6 & -27.1 & 10,123 & 2,348 & 106.9 & 1.9 \\
\hline Lesotho & 34 & 49 & 0.02 & 20 & 13.2 & 7.0 & 358 & 1,237 & 50.6 & 54.3 \\
\hline Malawi & 41 & 126 & 2 & 49 & 12.0 & 40.7 & 419 & 1,285 & 14.3 & 33.7 \\
\hline Mozambique & 313 & 4,742 & 0.09 & 2 & 30.5 & 186.8 & 1,505 & 20,967 & 36.9 & 136.8 \\
\hline Zambia & 264 & 1,550 & $\ldots$ & -174 & 31.6 & 28.4 & 4,038 & 14,260 & 110.5 & 63.6 \\
\hline
\end{tabular}


Policy Options for Promoting FDI in the LDCs

Annex table (continued)

\begin{tabular}{|c|c|c|c|c|c|c|c|c|c|c|}
\hline & \multicolumn{2}{|c|}{$\begin{array}{l}\text { Average annual FDI inflows } \\
\text { (US dollars, millions) }\end{array}$} & \multicolumn{2}{|c|}{$\begin{array}{c}\text { Average annual FDI outflows } \\
\text { (US dollars, millions) }\end{array}$} & \multicolumn{2}{|c|}{$\begin{array}{l}\text { FDI inflows as percentage of } \\
\text { gross fixed capital formation }\end{array}$} & \multicolumn{2}{|c|}{$\begin{array}{c}\text { Inward FDI stock (US dollars, } \\
\text { millions) }\end{array}$} & \multicolumn{2}{|c|}{$\begin{array}{c}\text { Inward FDI stock as percentage } \\
\text { of } G D P\end{array}$} \\
\hline & $2001-2003$ & $2011-2013$ & $2001-2003$ & $2011-2013$ & $2001-2003$ & $2011-2013$ & 2001 & 2013 & 2001 & 2013 \\
\hline Asia and the Pacific & 838 & 5,040 & 52 & 130 & 3.9 & 5.7 & 9,234 & 33,679 & 10.7 & 10.7 \\
\hline South-East Asia & 371 & 3,899 & 8 & 24 & 16.8 & 15.5 & 5,646 & 17,180 & 42.4 & 19.5 \\
\hline Cambodia & 126 & 1,219 & 8 & 36 & 17.0 & 50.1 & 1,729 & 9,399 & 43.3 & 60.0 \\
\hline Lao People's Democratic Republic & 16 & 297 & 0.1 & -9 & 4.8 & 10.4 & 612 & 2,779 & 36.3 & 27.8 \\
\hline Myanmar & 225 & 2,355 & $\ldots$ & $\ldots$ & 22.4 & 12.4 & 3,305 & 14,171 & 43.3 & 25.1 \\
\hline Timor-Leste & 5 & 28 & & -3 & 4.0 & 3.6 & 0 & 230 & & 3.7 \\
\hline South Asia & 393 & 1,535 & 10 & 33 & 2.3 & 2.7 & 2,341 & 10,910 & 3.8 & 6.0 \\
\hline Afghanistan & 36 & 82 & & $\ldots$ & 6.8 & 2.6 & 18 & 1,638 & 0.5 & 7.9 \\
\hline Bangladesh & 344 & 1,343 & 10 & 33 & 2.5 & 3.6 & 2,202 & 8,596 & 4.3 & 6.1 \\
\hline Bhutan & 3 & 23 & & $\ldots$ & 0.8 & 1.9 & 4 & 163 & 0.9 & 8.2 \\
\hline Nepal & 10 & 87 & $\ldots$ & $\ldots$ & 0.8 & 2.3 & 116 & 514 & 2.0 & 2.7 \\
\hline West Asia & 60 & -394 & 34 & 73 & 3.5 & -7.5 & 998 & 3,675 & 8.9 & 9.4 \\
\hline Yemen & 60 & -394 & 34 & 73 & 3.5 & -7.5 & 998 & 3,675 & 8.9 & 9.4 \\
\hline Oceania & 13 & 176 & -0.4 & 6 & 10.8 & 28.7 & 249 & 1,915 & 27.8 & 68.5 \\
\hline Kiribati & 0.2 & 4 & 0.1 & -0.2 & 0.5 & 4.8 & 0.7 & 14 & 1.2 & 8.0 \\
\hline Samoa $^{1}$ & 0.5 & 22 & -1.7 & 3 & 5.2 & 35.6 & 72 & 282 & 30.2 & 40.1 \\
\hline Solomon Islands & -5 & 107 & 0.6 & 3 & -9.6 & 41.8 & 97 & 1,040 & 28.9 & 94.8 \\
\hline Tuvalu & $\ldots$ & $\ldots$ & $\ldots$ & $\ldots$ & $\ldots$ & & $\ldots$ & $\ldots$ & $\ldots$ & $\ldots$ \\
\hline Vanuatu & 18 & 44 & 0.5 & 0.6 & 40.5 & 19.8 & 79 & 578 & 30.6 & 70.4 \\
\hline Caribbean & 8 & 155 & $\ldots$ & $\ldots$ & 2.0 & 13.7 & 100 & 1,114 & 3.1 & 13.2 \\
\hline Haiti & 8 & 155 & $\ldots$ & $\ldots$ & 2.0 & 13.7 & 100 & 1,114 & 3.1 & 13.2 \\
\hline \multicolumn{11}{|l|}{ Memorandum: } \\
\hline Total, developing countries & 195,677 & 744,220 & 62,734 & 438,937 & 11.3 & 9.4 & $1,875,636$ & $8,483,009$ & 26.9 & 31.1 \\
\hline Total, developed countries & 478,526 & 654,232 & 554,029 & 975,284 & 7.9 & 7.7 & $5,629,969$ & $16,053,149$ & 22.3 & 36.4 \\
\hline Total, world & 687,780 & $1,494,107$ & 622,542 & $1,489,673$ & 8.8 & 8.8 & $7,589,721$ & $25,464,173$ & 23.3 & 34.3 \\
\hline
\end{tabular}

Source: UNCTAD, World Investment Report 2014: Investing in the SDGs - An Action Plan, available at:

http://unctad.org/en/pages/PublicationWebflyer.aspx?publication id=937 (Quick links), (last visited 26 June 2014), annex tables 1,2,3,5 and 7.

Notes: Figures in columns 1-6 are three-year averages calculated on the basis of the annual data for the relevant years provided by the tables in the source cited.

Three dots (...) indicate that data are not available or are not separately reported.

A blank indicates that the item is not applicable.

${ }^{1}$ Samoa has graduated from the LDC status on 1 January 2014. 